\title{
Ternary Copper Complex of L-Glutamine and Phenanthroline as Counterions of Cyclo-Tetravanadate Anion: Experimental-Theoretical Characterization and Potential Antineoplastic Activity
}

\author{
Nidia D. Corona-Motolinia ${ }^{1} \mathbb{D}$, Beatriz Martínez-Valencia ${ }^{1} \mathbb{D}$, Lisset Noriega ${ }^{2}$, Brenda L. Sánchez-Gaytán ${ }^{1}(\mathbb{D}$ \\ Angel Mendoza ${ }^{1}$ (D), Francisco J. Meléndez-Bustamante ${ }^{2}$, María Eugenia Castro ${ }^{1, *(D)}$ \\ and Enrique González-Vergara ${ }^{1, *(1)}$
}

1 Centro de Química del Instituto de Ciencias, Benemérita Universidad Autónoma de Puebla, 18 sur y Av. San Claudio, Col. San Manuel, Puebla 72570, CP, Mexico; nidia.corona@alumno.buap.mx (N.D.C.-M.); beatriz.mvalencia@alumno.buap.mx (B.M.-V.); brendale.sanchez@correo.buap.mx (B.L.S.-G.); angel.mendoza@correo.buap.mx (A.M.)

check for updates

Citation: Corona-Motolinia, N.D.; Martínez-Valencia, B.; Noriega, L.; Sánchez-Gaytán, B.L.; Mendoza, A.; Meléndez-Bustamante, F.J.; Castro, M.E.; González-Vergara, E. Ternary Copper Complex of L-Glutamine and Phenanthroline as Counterions of Cyclo-Tetravanadate Anion: Experimental-Theoretical Characterization and Potential Antineoplastic Activity. Metals 2021 11, 1541. https://doi.org/10.3390/ met11101541

Academic Editors: Manuel Aureliano, Nadiia I. Gumerova and Annette Rompel

Received: 9 September 2021

Accepted: 22 September 2021

Published: 27 September 2021

Publisher's Note: MDPI stays neutral with regard to jurisdictional claims in published maps and institutional affiliations.

Copyright: (C) 2021 by the authors Licensee MDPI, Basel, Switzerland. This article is an open access article distributed under the terms and conditions of the Creative Commons Attribution (CC BY) license (https:// creativecommons.org/licenses/by/ $4.0 /)$
2 Facultad de Ciencias Químicas, Benemérita Universidad Autónoma de Puebla, 18 sur y Av. San Claudio, Col. San Manuel, Puebla 72570, CP, Mexico; lisset.noriegad@alumno.buap.mx (L.N.); francisco.melendez@correo.buap.mx (F.J.M.-B.)

* Correspondence: mareug.castro@correo.buap.mx (M.E.C.); enrique.gonzalez@correo.buap.mx (E.G.-V.); Tel.: +52-222-363-0623 (E.G.-V.)

\begin{abstract}
Over the last decade, therapeutic metallodrugs have become substantially effective in the treatment of cancer. Thus, developing new effective anticancer drugs is a significant research area against the continuing increase in cancers worldwide. In the search for heterobimetallic prodrugs containing $\mathrm{V} / \mathrm{Cu}$, a new cyclo-tetravanadate was synthesized and characterized by UV-visible and FTIR spectroscopies and single-crystal X-ray diffraction. L-Glutamine and 1,10-phenanthroline allow the crystallization of $\left[\mathrm{Cu}(\mathrm{L}-\mathrm{Gln})(\text { phen })\left(\mathrm{H}_{2} \mathrm{O}\right)\right]_{4}\left[\mathrm{~V}_{4} \mathrm{O}_{12}\right] \cdot 8\left(\mathrm{H}_{2} \mathrm{O}\right)(\mathbf{1})$, in which the cyclo-tetravanadate acts as a free anion. Density functional theory (DFT) calculations were carried out to characterize the frontier molecular orbitals and molecular electrostatic potential. Global reactivity indexes were calculated and analyzed to give insight into the cyclo-tetravanadate anion and complex counterions interactions. Also, using Bader's theory of atoms in molecules (AIM), non-covalent interactions were analyzed. Docking analysis with the Casiopeina-like complex resulting from the hydrolysis of compound 1 provided insights into these complex potential anticancer activities by interacting with DNA/tRNA via H-bonds and hydrophobic interactions. The release of both components could act together or separately, acting as prodrugs with potential dual antineoplastic activities.
\end{abstract}

Keywords: mixed copper complexes; Cyclo-tetravanadates; L-Glutamine; Phenanthroline DFT calculations; molecular docking; antineoplastic activity

\section{Introduction}

The synthesis of metallodrugs for cancer treatment has been rising due to its substantial success in the last decade [1,2]. Cancer is a multi-factorial, multibillion-dollar public health epidemic around the world. Considering that in 2020 there were approximately 18.1 million new cases and 9.6 million deaths worldwide, it is important to find safe and low-cost ways to fight it [3]. In the Region of the Americas, it is the second leading cause of death. If no steps are taken to prevent and control cancer, the number of persons diagnosed with cancer will rise by 55 percent by 2040, totaling roughly 6.23 million people. [4]. About 195,499 new cases and 90,222 deaths were estimated in Mexico in 2020, with a higher prevalence of breast cancer, followed by prostate cancer with $15.3 \%$ and $13.7 \%$, respectively [3]. While several drugs containing metals based on gold, ruthenium, gallium, 
titanium, iron, and copper are in preclinical and clinical phase I and II trials [5,6], the most effective antitumor agents used in clinical practice remain cis-platinum and also second- and third-generation platinum coordination compounds (carboplatin, oxaliplatin, and picoplatin). Nevertheless, platinum-based products' clinic use carries significant side effects, including nephrotoxicity, neurotoxicity, ototoxicity, hepatotoxicity, and myelosuppression $[7,8]$. Endogenous metal-based antitumor drugs ( $\mathrm{Co}, \mathrm{Cu}, \mathrm{Zn}$, and $\mathrm{Fe})$ are less toxic than platinum analogs and display promising pharmacological properties $[9,10]$.

In the specific case of copper, it provides an ideal geometry to interact with DNA molecules, making them a viable alternative to platinum-based anticancer drugs, with the advantage that copper is better tolerated and can be more easily managed in vivo than other transition metals [11,12]. Complexes containing symmetric aromatic binders, such as 1,10-phenanthroline and 2,2'-bipyridine, and how they interact with DNA have received much attention [13-16]. In 1979, Sigman et al. discovered the first metallonuclease by demonstrating that $\left[\mathrm{Cu}(\mathrm{phen})_{2}\right]^{2+}$ complex inhibits DNA and RNA polymerase activity and can induce DNA strand scission [17]. Numerous studies since then have demonstrated that the geometry of the metal center, combined with planar bidentate ligands, contains an optimal structure for interacting with a wide variety of biological molecules and possesses antitumoral and antiviral properties [18-22]. The synthesis, design, and development of complexes as anticancer agents have been presented in several reviews over the last decade, indicating an exponential increase in the field [23-35]. Ng et al. (2014) showed that copper(II) complexes containing 1,10-phenanthroline and amino acids were significantly more antiproliferative and induced more apoptotic cell death in the cisplatin-resistant MDA-MB-231 cells than in the non-cancerous MCF10A cells, and only induced cell cycle arrest in cancer cells. Additionally, these compounds were found to be effective against cervical (HeLa), ovarian (SKOV3), lung (A549, PC9), non-small cell lung (NPC) (Hone1, HK1, C666-1), breast (MCF7, T47D), lymphoma and leukemia (Nalmawa, HL60), and colorectal (SW480, SW48, HCT118) cancer cell lines with IC50 values $(24 \mathrm{~h})$ ranging from 1.7 to $19.0 \mu \mathrm{M}$. Importantly, these compounds were even more effective than cisplatin in some cases [36]. A series of ternary copper(II)-L-dipeptide-neocuproine complexes demonstrated cytotoxicity against cancer cells, including the triple-negative breast cancer cell line MDA-MB-231 [37]. The complex bis[(2-chloro)chloro(1,10-phenanthroline)copper(II)] exhibited a high degree of reactivity. Anticancer activity was observed against the B16, MDA-MB-32, A549, HT-29, and SF cell lines, with an average of IC50 of $0.726 \mathrm{~g} / \mathrm{mL}$ $(1.15 \mu \mathrm{M})$, compared to cisplatin's $4.88 \mathrm{~g} / \mathrm{mL}(16.3 \mu \mathrm{M})$. Furthermore, it demonstrated a higher selectivity for cancer cells than human bone marrow stem cells, and in rats, it is less toxic than cisplatin [38]. Copper-based metallodrugs loaded in nanoparticles have also shown promising results. The survival rate of a murine B16 melanoma model, when given chitosan nanoparticles loaded with Cassiopeina, was higher than those that received the drug as such. This was achieved due to a longer residence time at the site of action because the release of the substance from the nanoparticles was achieved at the acidic $\mathrm{pH}$ of the tumor [39]. Reina et al. have synthesized second-generation Casiopeina ${ }^{\circledR}$ [40] by substituting acetylacetonate for 2-aminomethyl benzimidazole (2AMB) as a bidentate chelate ligand. The change increases hydrophilicity and antiproliferative activity, resulting in two active complexes against the human tumoral cell lines, HeLa and MCF-7. A small group of copper complex exerts an effective inhibitory action on topoisomerases, which participate in the regulation of DNA topology. Copper complexes of topoisomerase inhibitors work via different molecular mechanisms that affect the cell cycle checkpoints and death effectors. Expanding this family of highly active anticancer drugs and their use with other emerging cancer therapies opens new avenues for treating cancers [28]. Complexes of $\mathrm{Cu}$ (II)-phenanthroline with L-asparagine and L-methionine were highly toxic to the prostate cancer cell lines (DU-145 and PC3), breast cancer cell lines (MDA-MB-231 and MCF7), and MV3 (melanoma) [41]. The mechanism is a redox reaction of $\mathrm{Cu}$ (II)/Cu (I) that catalyzes the formation of reactive oxygen species (ROS). The structure of this type of complex consists of a copper(II) core with a distorted square pyramidal geometry, 
which, in the presence of ascorbate, exhibits effective DNA cleavage activity at micromolar concentrations, producing hydroxyl radicals as the active species [42]. Recently, it has been demonstrated that sulfonamide copper(II) complexes with 1,10-phenanthroline and $2,2^{\prime}$-bipyridine possess potent nuclease activities with antiproliferative and anti-M. tuberculosis actions [43]. Casiopeinas ${ }^{\circledR}$ have gained an important place in the efforts to generate antineoplastic drugs with copper, as expressed in the recent invention of a safe parental solution with Cassiopeia III-ia [44]. In the review of copper coordination compounds as biologically active agents," it is stated that the redox activity of copper ions, as well as the stability of copper coordination compounds in the bloodstream, and the extremely encouraging therapeutic outcomes both in vitro and in vivo, show the potential of copper coordination compounds, which is expected to gain widespread clinical use" [45].

Vanadium, on the other hand, has therapeutic properties that are well known. Its pharmacological properties could be used to treat diabetes, however, concern about toxicity is still an issue $[46,47]$. However, some studies have also shown that vanadium could be used to treat cancer since it causes cell apoptosis, displaying cytotoxic and antiproliferative effects [48]. In fact, several of the metabolic pathways are used by both diabetes mellitus and cancer [49-52]. Recent studies of pancreatic cancer, malignant melanoma, glioma multiforme, and an aggressive brain cancer have shown that vanadates and oligovanadates function as anticancer drugs [53-55]. Also, in cytotoxicity experiments with human osteosarcoma (MG-63) and human colorectal adenocarcinoma (HT-29) cell lines, the compound bis (4,7-dimethyl-1,10-phenanthroline) sulfatooxidovanadium (IV), known as Metvan, showed altered cell viability of both cancer cell lines in the low concentration range $(0.25-5.0 \mu \mathrm{M})[56]$. Another recent study showed the importance of the interaction of polyoxovanadates with the plasma membrane to subsequently hydrolyze and internalize the compound, thus allowing partial participation in the generation of ROS and electron transfer processes $[57,58]$. In addition, vanadium-based nanomaterials have been found to be helpful for theranostic applications. Vanadium nitride nanosheets are readily convertible into biocompatible materials that display near-infrared (NIR) absorption, producing ROS and effectively killing cancerous tissue [59]; vanadium oxide has an activity similar to peroxide, which would be helpful in tumor-specific chemodynamic therapy [60]. In addition, it is well known that oxidovanadium complexes with organic ligands have cytotoxic or differentiating properties against various cancer cell types [61-66]. However, their limited use in clinical trials stems primarily from concerns about the long-term toxicity of such complexes due to a lack of data. However, recent administration of [VO(HSHED)dtb] complex in mice did not show any signs of toxicity up to a dose of $300 \mathrm{mg} / \mathrm{kg}$. The complex was less toxic than orthovanadate salt, consistent with the compound being partially intact during the administration [67]. The low toxicity is attributed to the redox properties obtained when combining the redox-active ligand 3,5-di(tert-butyl)catechol with the hydrolytic stability of the [VO(HSHED)dtb], which prevent the formation of the vanadate and catechol ligand. These results point out that the protection of even anionic vanadium species may help increase activity and reduce toxicity. Although anionic compounds of vanadium can survive the transit in the bloodstream and enter the cell by several mechanisms, it is possible to suggest that they generate mainly V1, V2, and V4 vanadates through speciation $[63,64]$. Thus, it is crucial to investigate the cyclo-tetravanadate anion since it will be the primary species at physiological $\mathrm{pH}$ [68]. Anionic compounds of vanadium(V) have shown interesting anticancer properties $[69,70]$. Recently, the compounds $\left(\mathrm{NH}_{4}\right)_{4} \mathrm{Li}_{2} \mathrm{~V}_{10} \mathrm{O}_{28} \cdot 10 \mathrm{H}_{2} \mathrm{O}$ and $\mathrm{Mg}\left(\mathrm{H}_{2} \mathrm{O}\right)_{6}\left(\mathrm{C}_{4} \mathrm{~N}_{2} \mathrm{H}_{7}\right)_{4} \mathrm{~V}_{10} \mathrm{O}_{28} \cdot 4 \mathrm{H}_{2} \mathrm{O}$ demonstrated dose-dependent antiproliferative activity on human cancer cells U87, IGR39, and MDA-MB-231 [71,72]. Again, nanotechnology provides new possibilities. Cationic liposomes have been used to encapsulate a hydrophobic oxidovanadium complex that has shown cytotoxic properties against neuroblastoma cell lines while also improving bioavailability [73]. V(IV)-curcumin-bipyridine (VCur) was encapsulated in vitro using magnetic cationic liposomes, which gives the compound excellent stability and solubility in physiological media [74]. Biocompatible vanadium nitride nanosheets have shown relevant near-infrared (NIR) absorption that can be used 
for imaging and produce reactive oxygen species upon NIR excitation, effectively killing cancer tissue. Recent studies of eleven vanadium species, compounds, and materials, in several human melanoma cells lines, have shown interesting antitumor capabilities to a variety of effects, including: (1) cell viability, (2) cell morphology changes and apoptosis, (3) cell-cycle arrest, (4) ROS production, (5) mitochondrial dysfunction, (6) protein expression, and (7) in vivo tumor regression and survival rates. Therefore, it was concluded that essential questions would be answered this decade to push forward the practice of metals compounds-particularly vanadium - to treat cancer [75].

As for copper, the new results and new strategies for delivery point to significant advances in this decade. It is essential to consider that compounds of vanadium and copper will act as prodrugs since they will undergo interactions with proteins such as human serum albumin and transferrin, and these will release their ligands, or in some robust cases, transport of the intact prodrug in the bloodstream could take place [76-81]. Speciation outside or inside the cells is most probable, but regardless of this, important anticancer actions are provided by polyoxidovanadates (POVs) and Casiopeinas ${ }^{\circledR}$, so we expect dual anticancer activities of the compounds reported here. It is now clear that both metals will provide new metallodrugs to help in the global problem of cancer treatment in the near future. Also, POVs have a diverse spectrum of structural, biological, and pharmacological properties that are intriguing and potentially useful. Recent research has indicated that these compounds may effectively treat solid tumors, DNA and RNA viruses, and drugresistant bacteria. Changes in cell structure, interference with the ion transport system, inhibition of mRNA synthesis, and disruption of metabolic pathways and communication mechanisms are all known antibacterial modes of action for various POVs. Additionally, POVs have been found to reduce mitochondrial respiration in vitro. However, in the future, researchers need to explore vanadium-containing POV-based nanohybrids rather than pure POVs to reduce toxicity and boost efficacy [82].

As the first collection of $\mathrm{V} / \mathrm{Cu}$ heterobimetallic compounds with the potential to be used as metallodrugs in cancer treatment, our group has identified several cyclotetravanadates [83-85]. We recently reported the synthesis and theoretical-experimental characterization of two compounds resulting from our quest to complete the family of copper cyclo-tetravanadate complexes. Interestingly, the compounds obtained were different, although the same synthetic technique was used; however, it is possible to consider them Casiopeina ${ }^{\circledR}$ analogs [86]. Here, a new cyclo-tetravanadate is presented. This compound was characterized by visible and IR spectroscopies as well as single-crystal X-ray diffraction. In addition, the compound was studied using DFT computational methods. The frontier molecular orbitals and global reactivity indexes were analyzed to show interesting characteristics about the donor-acceptor interactions. These insights about the compound's reactivity were corroborated by analyzing the non-covalent interactions using the AIM approach. The Casiopeina-like complex in docking studies shows the potential to interact with DNA/RNA, thus providing a new compound with potential dual anticancer activity in various cell lines.

\section{Results}

Compound 1 crystallizes in the triclinic space group P1, with only one asymmetric unit filling the unit cell. Figure 1 shows a representation of the molecule and Table 1 presents the corresponding crystal data. The compound contains four $\left[\mathrm{Cu}(\mathrm{L}-\mathrm{Gln})(\mathrm{phen})\left(\mathrm{H}_{2} \mathrm{O}\right)\right]^{+}$ cations displaying a squared-pyramidal geometry $\left(\tau_{5}=0.017\right)$, of which the two $\mathrm{N}$ donors of phenanthroline and the amino and carboxyl groups of glutamine are coordinated in basal positions. As shown in Figure 1, four water molecules occupy the apical positions of all the square pyramids. In this case, the glutamine ligands are L isomers. However, two hydrogen atoms in the alpha carbon point in the opposite direction of the coordinated water, so they are considered anti-conformers; the other two pointing in the same direction are considered syn-conformers, as seen in Figures 2 and 3. It can be observed that all copper coordination compounds interact non-covalently with the cyclo-tetravanadate structure 
through different hydrogen bonds. Figure 2 shows the hydrogen bonds surrounding the cyclo-tetravanadate anion. Eight $\mathrm{H}_{2} \mathrm{O}$ molecules stabilize the structure, five of them (O33 to O37) in a chain array connecting one complex molecule with the $\left[\mathrm{V}_{4} \mathrm{O}_{12}\right]^{4-}$ anion. Tables S1-S5, Supplementary Materials contain more details of structural data.

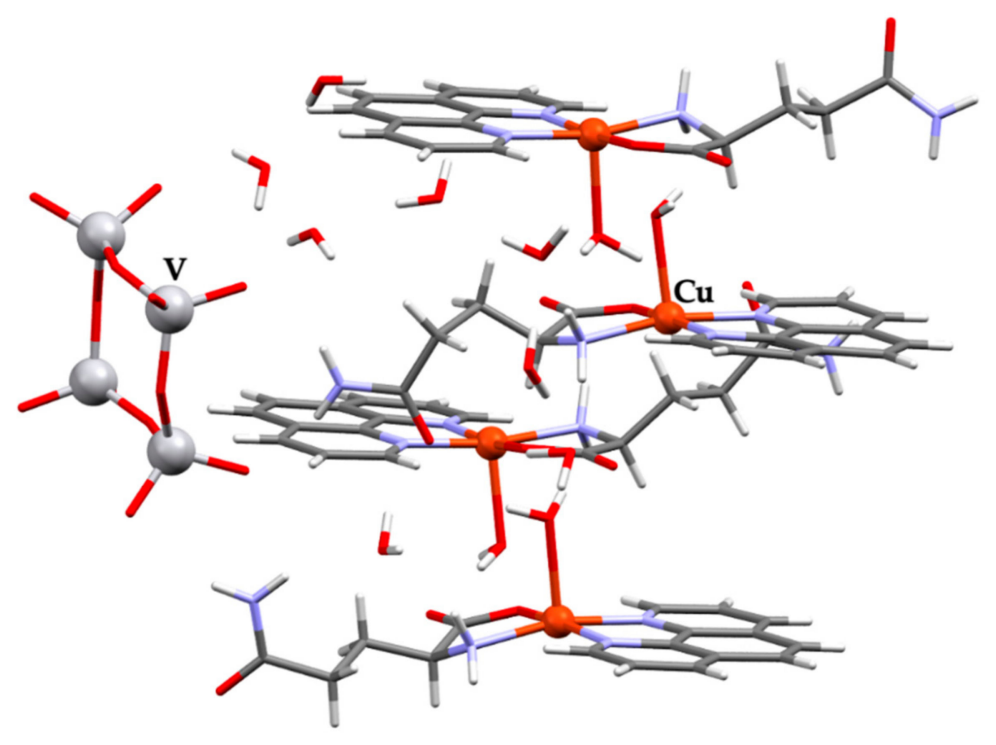

Figure 1. Representation of Compound 1, where $\left[\mathrm{Cu}(\mathrm{L}-\mathrm{Gln})(\mathrm{phen})\left(\mathrm{H}_{2} \mathrm{O}\right)\right]^{+}$neutralize $\left(\mathrm{V}_{4} \mathrm{O}_{12}\right)$ anion. L-glutamine is present as two syn and two anti-conformers, data from [87].

Table 1. Crystal data and structure refinement for Compound $\mathbf{1 .}$

\begin{tabular}{|c|c|}
\hline Chemical formula & $\left(\mathrm{C}_{17} \mathrm{H}_{19} \mathrm{CuN}_{4} \mathrm{O}_{4}\right)_{4} \mathrm{~V}_{4} \mathrm{O}_{12} \cdot 8\left(\mathrm{H}_{2} \mathrm{O}\right)$ \\
\hline$M_{\mathrm{r}}$ & 2167.49 \\
\hline Crystal system, space group & Triclinic, P1 \\
\hline Temperature (K) & 293.15 \\
\hline$a, b, c(\AA)$ & $12.3849(3), 14.1023(3), 14.1516(3)$ \\
\hline$\alpha, \beta, \gamma\left({ }^{\circ}\right)$ & $68.967(2), 71.327(2), 77.252(2)$ \\
\hline$V\left(\AA^{3}\right)$ & $2169.86(9)$ \\
\hline$Z$ & 1 \\
\hline Radiation type & Mo K $\alpha$ \\
\hline$\mu\left(\mathrm{mm}^{-1}\right)$ & 1.47 \\
\hline Crystal size (mm) & $0.35 \times 0.17 \times 0.10$ \\
\hline Absorption correction & Gaussian \\
\hline $\begin{array}{l}\text { No. of measured, independent and observed }[I>2 \sigma(I)] \\
\text { reflections }\end{array}$ & 59,$756 ; 21,452 ; 17,760$ \\
\hline$R_{\text {int }}$ & 0.058 \\
\hline$(\sin \theta / \lambda)_{\max }\left(\AA^{-1}\right)$ & 0.667 \\
\hline$R\left[F^{2}>2 \sigma\left(F^{2}\right)\right], w R\left(F^{2}\right), S$ & $0.045,0.111,1.02$ \\
\hline No. of reflections & 21,452 \\
\hline No. of parameters & 1171 \\
\hline H-atom treatment & $\begin{array}{l}\text { H-atom parameters constrained } \\
\text { research papers }\end{array}$ \\
\hline$\Delta_{\max } \Delta_{\min }\left(\mathrm{e} \AA^{-3}\right)$ & $1.03,-0.29$ \\
\hline
\end{tabular}




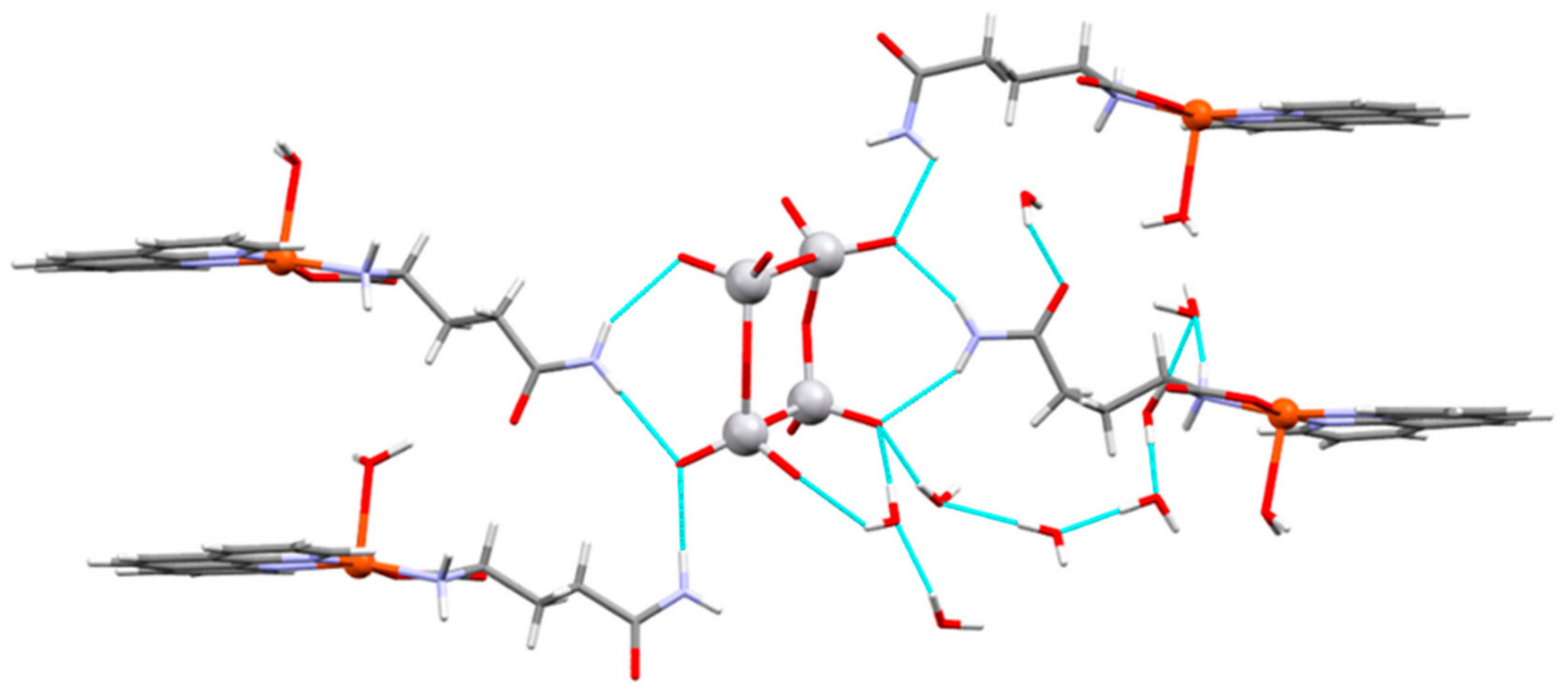

Figure 2. Representation of Compound 1, where anti-conformers are on the right and syn-conformers are on the left. Blue lines indicate hydrogen bonds.
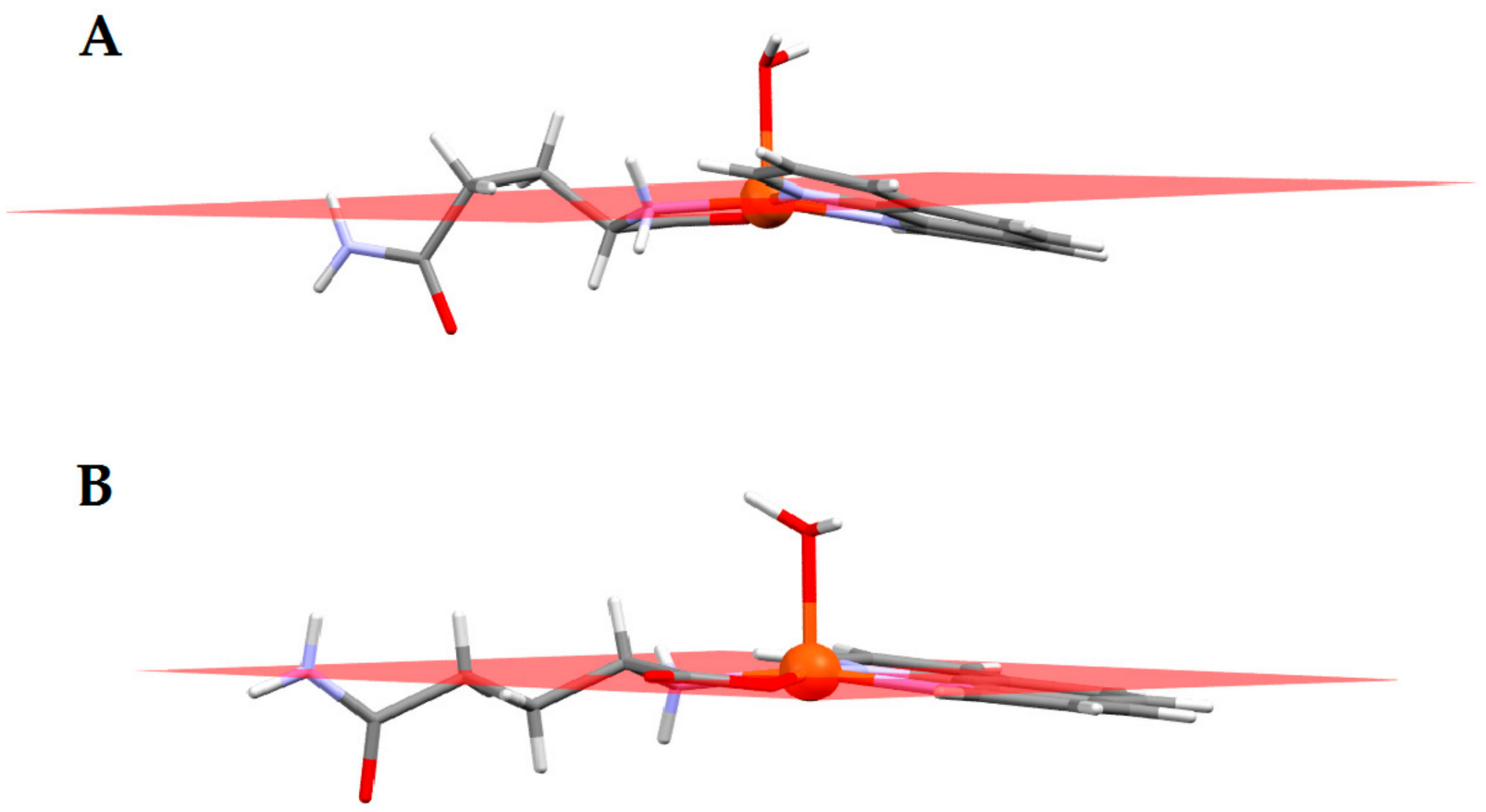

Figure 3. (A) anti-conformer and (B) syn-conformer of $\left[\mathrm{Cu}(\mathrm{L}-\mathrm{Gln})(\mathrm{phen})\left(\mathrm{H}_{2} \mathrm{O}\right]^{+}\right.$.

\subsection{Infrared Spectroscopy}

Due to the relatively rigid structure of the polyoxovanadate ions, the IR spectra of the individual types of polyoxovanadates have characteristic bands in the region of asymmetric and symmetric VO stretching vibrations. As a result, IR spectroscopy can be used to characterize such compounds [88-90]. The spectrum of Compound $\mathbf{1}$ in the region $1000-500 \mathrm{~cm}^{-1}$ is presented in Figure 4. The complete spectrum is presented in Figure S1 in the Supplementary Materials. Bands resulting from the symmetric and asymmetric vibrations of terminal $\mathrm{V}\left(\mathrm{O}_{\mathrm{t}}\right)_{2}$ commonly occur between $910-1000 \mathrm{~cm}^{-1}$ for $v_{\text {as }}$ and $860-900 \mathrm{~cm}^{-1}$ for $v_{\mathrm{s}}$. On the other hand, bands below $850 \mathrm{~cm}^{-1}$ could be assigned to the asymmetric vibrations of the bridging $\mathrm{V}-\mathrm{O}_{\mathrm{b}}-\mathrm{V}$ groups, and the small band at $530 \mathrm{~cm}^{-1}$ 
could be assigned to $v_{\mathrm{s}} \mathrm{V}-\mathrm{O}_{\mathrm{b}}-\mathrm{V}$ [91-97]. The positions of absorption bands in the region of VO bond stretching vibrations (500-1000 $\mathrm{cm}^{-1}$ ) will make it possible to determine whether a compound's structure is made up of cyclic $\left[\mathrm{V}_{4} \mathrm{O}_{12}\right]^{4-}$ as a free anion or is involved in several hydrogen bond interactions, as shown in Figure 4. Compound 1 shows that cyclo-tetravanadate ions are involved in different hydrogen bond interactions, causing the splitting of the typical bands. Several shoulders appear in the main bands, indicating different $\mathrm{V}\left(\mathrm{O}_{\mathrm{t}}\right)_{2}$ and $\mathrm{V}-\mathrm{O}_{\mathrm{b}}-\mathrm{V}$ vibration strengths. These are seen in the inset, where the second derivative spectrum is depicted. The presence of several shoulders can be evidenced by second derivative spectroscopy [98-100]. The shoulders are now presented as peaks and show how different environments are experienced by each $\mathrm{VO}$ bond, consistent with the hydrogen bond interactions presented in the solid-state structures. As for the bands of phenanthroline, the only bands seen in this region are located at $727 \mathrm{~cm}^{-1}$ and $736 \mathrm{~cm}^{-1}$, respectively, and are assigned according to Schilt and Taylor [101] and Baskaran et al. [102], who observed two strong bands at $850 \mathrm{~cm}^{-1}$ and $725 \mathrm{~cm}^{-1}$ in the free ligand. The band at $850 \mathrm{~cm}^{-1}$ was assigned to the out-of-plane motion of the carbocyclic ring's hydrogen atoms and the $725 \mathrm{~cm}^{-1}$ to those of the two heterocyclic rings' hydrogen atoms. The band at $850 \mathrm{~cm}^{-1}$ is overlapped with the $\mathrm{V}-\mathrm{O}_{\mathrm{b}}-\mathrm{V}$ antisymmetric bands. As for the amino acid moiety, the strong bands of the amino and carboxylic groups are outside this region [103].

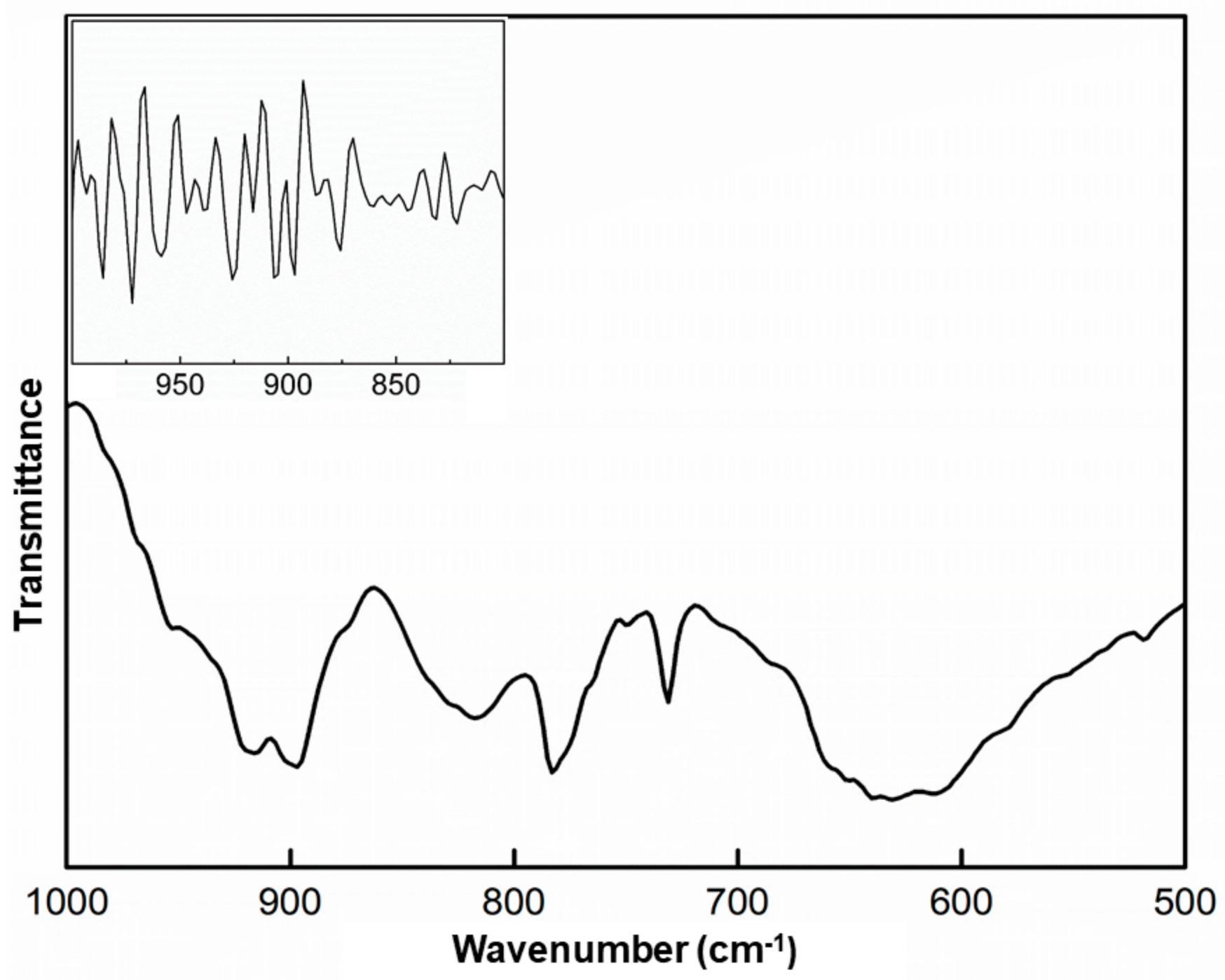

Figure 4. FTIR spectrum of Compound 1 in the $500-1000 \mathrm{~cm}^{-1}$ region. The inset shows the second derivative spectrum in the region $800-1000 \mathrm{~cm}^{-1}$. 


\subsection{Visible Spectroscopy}

Figure S2 shows the visible spectrum of Compound 1 after it had been dissolved in phosphate-buffered saline (PBS) solution at $\mathrm{pH}$ 7.4. Compound $\mathbf{1}$ showed an asymmetric absorption band at $\lambda_{\max }$ value $627 \mathrm{~nm}$, and a molar extinction coefficient $\varepsilon=45 \mathrm{~L} \mathrm{~mol}^{-1} \mathrm{~cm}^{-1}$. Valora et al., has shown that several ternary complexes containing 1,10-phenanthroline and amioacidates have d-d bands with $\lambda_{\max }$ value at $618 \pm 6 \mathrm{~nm}$ and $\varepsilon$ of $57 \pm 5$ due to the promotion of low energy d electrons to the $\mathrm{dx}^{2}-\mathrm{y}^{2}$ hole, which is the value expected for a $\mathrm{CuN}_{3} \mathrm{O}$ in-plane chromophore $[104,105]$. Thus, although in the solid-state, the geometry of the compound was a square pyramid, it is likely that in aqueous solution, the compound exhibits a unique molecular geometry, which is a tetragonally elongated octahedron.

\subsection{Computational Calculations}

The molecular structure, molecular electrostatic potential (MEP) map, and isosurfaces of the highest occupied molecular orbital (HOMO) and lowest unoccupied molecular orbital (LUMO) are shown in Figure 5.

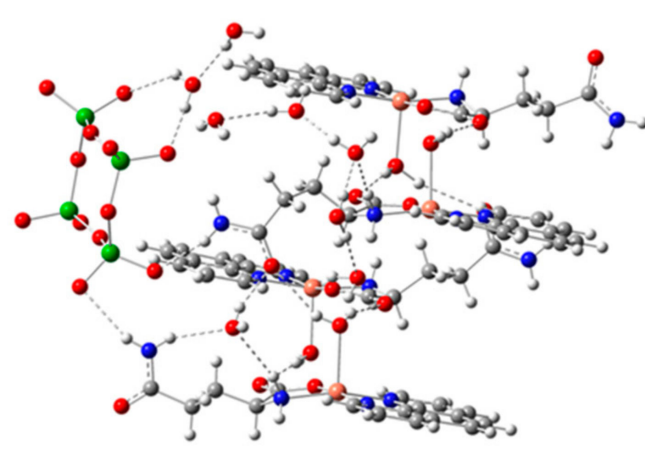

(a)

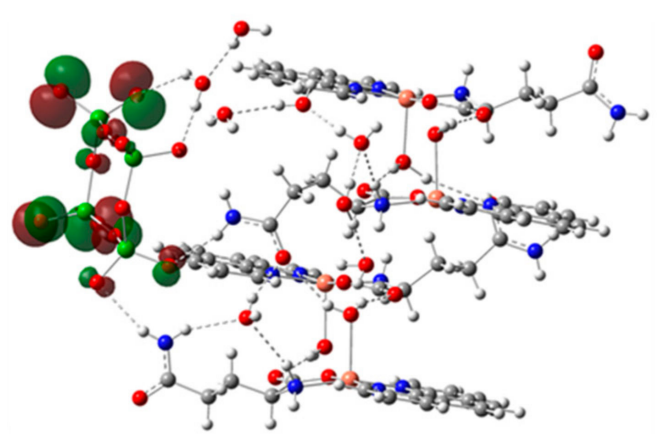

(c)

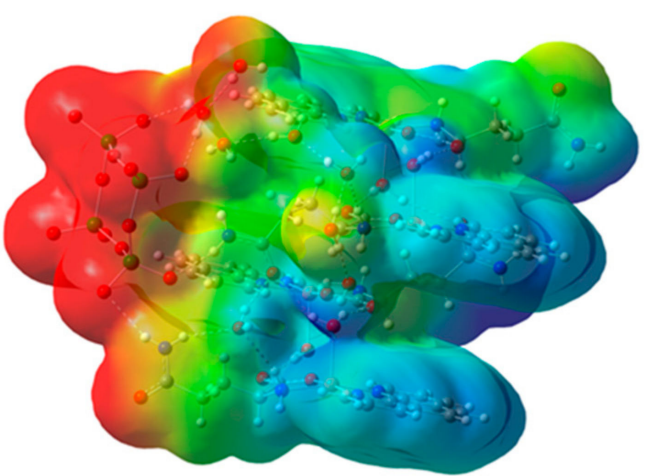

(b)

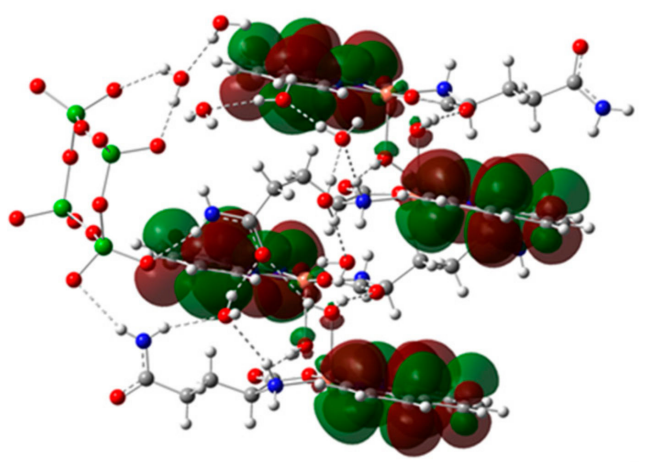

(d)

Figure 5. (a) Molecular structure, (b) molecular electrostatic potential (MEP), (c) HOMO isosurface, and (d) LUMO isosurface of Compound 1 at the B3LYP/Def2SVP-LANL2DZ level of theory using the ECP=LANL2DZ for $\mathrm{V}$ and $\mathrm{Cu}$ atoms in the PCM model.

The MEP distribution of Compound 1 shows the total electronic density mapped with the electrostatic potential using an isovalue of 0.004 a.u., in a range of -0.25 to $0.25 \mathrm{e} \mathrm{a.u.}{ }^{-3}$. The red region indicates the negative charge density on cyclo-tetravanadate anion (nucleophilic zone), while the positive charge is mainly located on glutamine and phenanthroline molecules (electrophilic zones). The non-covalent H-bonds between cyclotetravanadate and organic counterions and water molecules are located in intermediate regions of electron density (yellow-green regions) (see Figure $5 b$ ). Compound 1 shows the isosurfaces of the frontier molecular orbitals (FMO) using an isovalue of 0.03 a.u. 
(Figure 5c,d), showing significant contributions of phenanthroline and glutamine ligands for HOMO (-4.87 eV) and LUMO (-2.64 eV).

Global reactivity descriptors, such as chemical potential $(\mu)$, electronegativity $(\chi)$, hardness $(\eta)$, softness (s), and electrophilicity index $(\omega)$, were evaluated based on a conceptual DFT approach using the following equations: $\mu=\left(\mathrm{E}_{\mathrm{HOMO}}+\mathrm{E}_{\mathrm{LUMO}}\right) / 2$; $\chi=-\left(\mathrm{E}_{\mathrm{HOMO}}+\mathrm{E}_{\mathrm{LUMO}}\right) / 2 ; \eta=\mathrm{E}_{\mathrm{LUMO}}-\mathrm{E}_{\mathrm{HOMO}} ; \mathrm{s}=1 / \eta, \omega=\mu^{2} / 2 \eta$, where $\mathrm{E}_{\mathrm{HOMO}}$ and $\mathrm{E}_{\mathrm{LUMO}}$ are the frontier molecular orbitals energies. Table 2 shows the results.

Table 2. Global reactivity descriptors (in eV) of Compound 1 at the B3LYP/Def2SVP-LANL2DZ level of theory using the ECP = LANL2DZ for $\mathrm{V}$ and $\mathrm{Cu}$ atoms in the PCM model.

\begin{tabular}{cccccccc}
\hline & E $_{\text {HOMO }}$ & E $_{\text {LUMO }}$ & $\mu$ & $\chi$ & $\eta$ & s & $\omega$ \\
\hline Compound 1 & -4.8697 & -2.6351 & -3.7524 & 3.7524 & 2.2346 & 0.4475 & 3.1506 \\
\hline
\end{tabular}

The electron charge transfer process can be analyzed in terms of chemical potential ( $\mu$ ) (or electronegativity $(\chi=-\mu)$ ), hardness $(\eta)$ (or softness $\left(s=\eta^{-1}\right)$ ), and electrophilicity $(\omega)$. The results show that the chemical potential value, $\mu$, of Compound 1, indicates the capacity for exchanging electrons. The chemical hardness value, $\eta$, indicates the resistance for changing its electron distribution. On the other hand, the behavior of the electrophile or nucleophile can be related to a higher or lower $\omega$ index. In conjunction with the MEP analysis, global reactivity indexes give insights regarding the electrophilic or nucleophilic power of the compounds' sites, which is important for analyzing the interaction. Topological parameters were used to characterize intramolecular interactions, such as electron density $\rho(r)$, Laplacian $\nabla^{2} \rho(r)$, Lagrangian kinetic energy $G$, potential energy density $V$, Hamiltonian kinetic energy $H$, interaction energy $E_{H} \ldots \gamma$, and interatomic distance $D_{\text {inter }}$. Results are shown in Table S6. The positive values of $\nabla^{2} \rho(r)$ confirm the hydrogen bond behavior of the interactions, and the positive values of $\mathrm{H}(\mathrm{r})$ indicate hydrogen bonds of a purely electrostatic nature. The value of equation $H(r)=G(r)-$ $V(r)$ determines the molecular interaction regions, and interaction energy is calculated from equation $E_{H \cdots Y}=\frac{1}{2}|V(r)|$. The molecular graph for Compound $\mathbf{1}$ is shown in Figure 6. Cyan dots represent the bond critical points (BCPs), yellow dots represent the ring critical points (RCPs), and orange dots represent the cage critical points (CCPs). In Figure 6, the main H-bond interactions between $\mathrm{O}$ atoms of the cyclo-tetravanadate anion with water molecules and $\mathrm{H}$-atoms of glutamine are shown. Table S6 presents the $\rho(r)$ values for H-bonds larger than 0.0100 a.u. The maxima $\rho(r)$ were found for the intermolecular O12 $\cdots \mathrm{H} 20 \mathrm{D}, \mathrm{O} 17 \cdots \mathrm{H} 15 \mathrm{~A}, \mathrm{O} 7 \cdots \mathrm{H} 5 \mathrm{~A}$, and $\mathrm{O} 2 \cdots \mathrm{H} 10 \mathrm{~A}$, corresponding to the interactions between one of the $\mathrm{H}$-atoms of the water in the apical position of $\mathrm{Cu}$ with the $\mathrm{O}$ atom of the $-\mathrm{COO}^{-}$moiety of glutamine, see Figure 6 . Their $E_{H} \ldots$ Y values between $5.40-6.93 \mathrm{kcal} \mathrm{mol}^{-1}$ indicate the most stabilized interactions. In addition, the interactions O36 $\cdots$ H35A, O35 $\cdots$ H34B, and O40 $\cdots$ H38C between water molecules have high values of $\rho(r)$ with $E_{H} \ldots$ Y values between $5.71-6.59 \mathrm{kcal} \mathrm{mol}^{-1}$. It can be seen that a lot of RCPs are present, indicating the formation of rings and CCPs forming cage structures between glutamine and phenanthroline molecules, providing structural stability to the molecular structure of Compound 1. Regarding interactions $\mathrm{O}-\mathrm{Cu}$, four equivalent interactions between $\mathrm{Cu}$ and $\mathrm{O}$ atoms of water in apical position can be observed. These interactions (O5-Cu1, O10-Cu2, O15-Cu3 and $\mathrm{O} 20-\mathrm{Cu} 4)$ have interaction energy values between 13.02-16.44 kcal mol${ }^{-1}$. Similar behavior in the non-covalent interactions between $\mathrm{Cu}$ with amino acid was observed for the cyclo-tetravanadate complex $[\mathrm{Cu}(\mathrm{Lys})(\mathrm{phen})]_{2}\left[\mathrm{~V}_{4} \mathrm{O}_{12}\right]$ containing lysine and phenanthroline, specifically the $\mathrm{Cu}-\mathrm{N}$ and $\mathrm{Cu}-\mathrm{O}$ interactions [83]. 


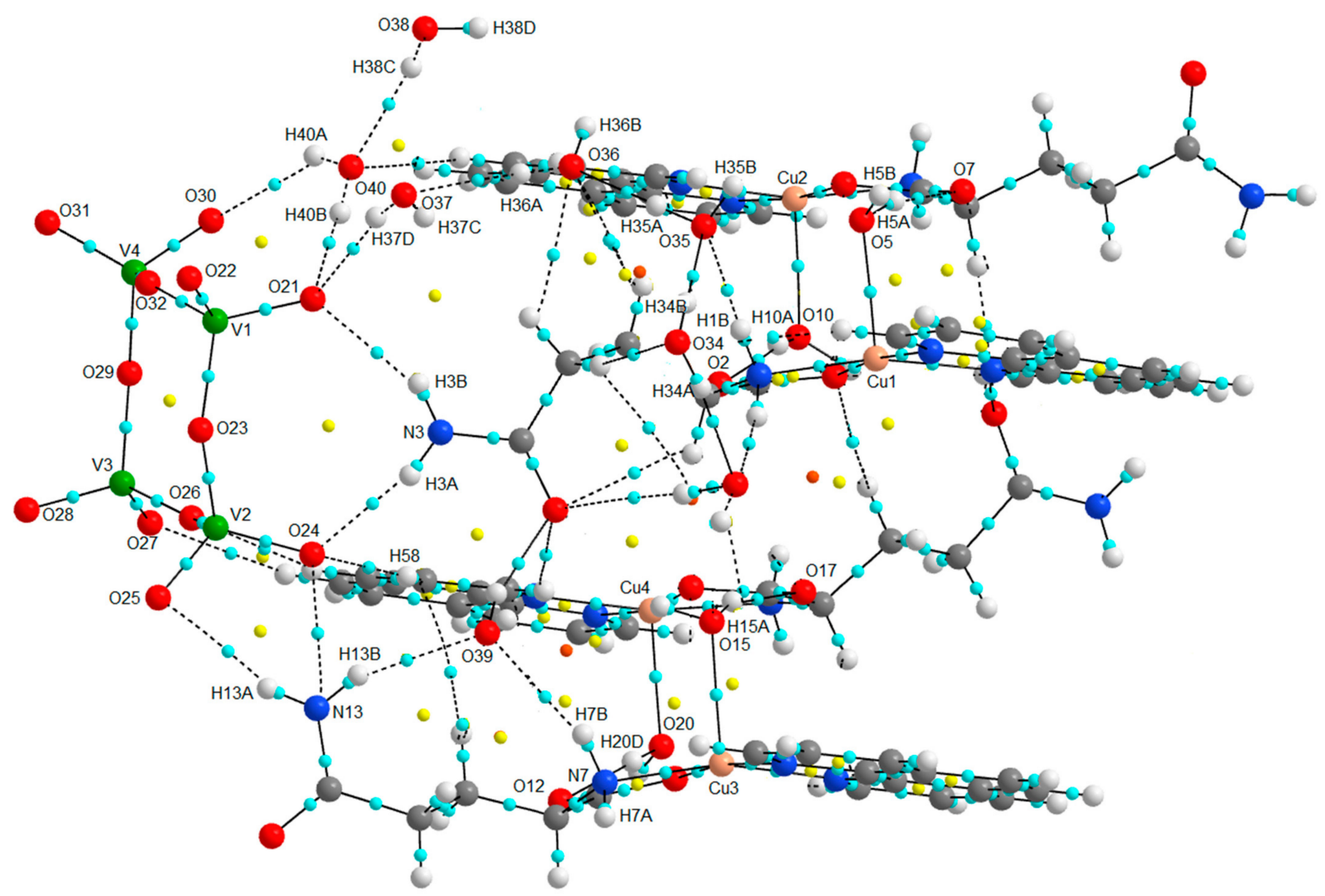

Figure 6. Molecular graph of the Compound 1 showing the main H-bonds between ions.

\subsection{Molecular Docking}

It was hypothesized that in an aqueous solution, because of reduction, re-oxidation, and hydrolysis, the vanadium and copper compounds would be released and act separately; thus, the copper Casiopeina like complex was studied as the corresponding aquo complex. In Table 3, the docked binding energies of the interaction with DNA/RNA test molecules, corresponding to the top molecular pose (lowest energy) for complex ions already reported, are presented for comparison.

Table 3. Molecular docking results, including the binding energies for the best molecular poses of doxorubicin and reported complexes with DNA and tRNA.

\begin{tabular}{ccccc}
\hline Compounds for Comparison & $\begin{array}{c}\text { Interaction } \\
\text { Energy } \\
\mathbf{k} \text { kcal/mol) } \\
\text { ADN 1BNA }\end{array}$ & $\begin{array}{c}\text { Interaction } \\
\text { Energy } \\
\mathbf{( k c a l / m o l )} \\
\text { ADN 151D }\end{array}$ & $\begin{array}{c}\text { Interaction Energy } \\
\text { (kcal/mol) } \\
\text { tRNA 6TNA }\end{array}$ & Interaction Type \\
\hline$*$ Doxorubicin & -11.09 & -11.54 & -9.82 & $\begin{array}{c}\text { H-bond, } \pi \text {-interaction, } \\
\text { van der Waals }\end{array}$ \\
\hline$*[\mathrm{Cu}(\mathrm{acac})(\mathrm{dmbipy})]^{1+} \mathrm{CAS} \mathrm{III} \mathrm{ia}$ & -7.47 & -8.76 & -6.16 & $\begin{array}{c}\text { H-bond, } \pi \text {-interaction, } \\
\text { van der Waals }\end{array}$ \\
\hline$*\left[\mathrm{Cu}(\text { phen })(\mathrm{Gly})\left(\mathrm{H}_{2} \mathrm{O}\right)\right]^{+} \mathrm{CAS}$ II-Gly & -10.57 & -8.86 & -9.47 & $\begin{array}{c}\text { H-bond, } \pi \text {-interaction, } \\
\text { van der Waals }\end{array}$ \\
\hline
\end{tabular}


Table 3. Cont.

\begin{tabular}{|c|c|c|c|c|}
\hline Compounds for Comparison & $\begin{array}{c}\text { Interaction } \\
\text { Energy } \\
(\text { kcal/mol) } \\
\text { ADN 1BNA }\end{array}$ & $\begin{array}{c}\text { Interaction } \\
\text { Energy } \\
(\text { kcal } / \text { mol }) \\
\text { ADN 151D }\end{array}$ & $\begin{array}{c}\text { Interaction Energy } \\
\text { (kcal/mol) } \\
\text { tRNA 6TNA }\end{array}$ & Interaction Type \\
\hline * $\left[\mathrm{Cu}(\right.$ hydroxynaphthaldehyde $\left.)\left(\mathrm{H}_{2} \mathrm{O}\right)\right]$ & -11.56 & -9.12 & -7.98 & $\begin{array}{l}\text { H-bond, } \pi \text {-interaction, } \\
\text { van der Waals }\end{array}$ \\
\hline * $\left[\mathrm{Cu}(\mathrm{Metf})(\mathrm{bipy})\left(\mathrm{H}_{2} \mathrm{O}\right)\right]^{2+}$ & -9.69 & -7.05 & -12.76 & $\begin{array}{c}\text { H-bond, } \\
\text { salt bridges, } \\
\text { van der Waals }\end{array}$ \\
\hline${ }^{*}\left[\mathrm{Cu}(\mathrm{Gly})(\operatorname{Impy})\left(\mathrm{H}_{2} \mathrm{O}\right)\right]^{+}$ & -8.82 & -6.73 & -8.83 & $\begin{array}{l}\text { H-bond, } \pi \text {-interaction, } \\
\text { van der Waals }\end{array}$ \\
\hline$\left[\mathrm{Cu}(\mathrm{Lys})(\mathrm{phen})\left(\mathrm{H}_{2} \mathrm{O}\right)\right]^{2+}$ & -11.03 & -9.98 & -8.86 & $\begin{array}{l}\text { H-bond, salt bridge, } \\
\pi \text {-interaction, van der } \\
\text { Waals }\end{array}$ \\
\hline$\left[\mathrm{Cu}(\mathrm{Orn})(\mathrm{bipy})\left(\mathrm{H}_{2} \mathrm{O}\right)\right]^{2+}$ & -11.12 & -9.68 & -13.15 & $\begin{array}{c}\text { H-bond, salt bridge, } \\
\pi \text {-interaction, van der } \\
\text { Waals, } \\
\text { Attractive charges }\end{array}$ \\
\hline$\left[\mathrm{Cu}(\mathrm{Gly})(\text { phen })\left(\mathrm{H}_{2} \mathrm{O}\right)\right]^{+}$ & -9.5 & -8.52 & -9.12 & $\begin{array}{c}\text { H-bond, } \pi \text {-interaction, } \\
\text { van der Waals }\end{array}$ \\
\hline$\left[\mathrm{Cu}(\mathrm{Orn})(\text { phen })\left(\mathrm{H}_{2} \mathrm{O}\right)\right]^{2+}$ & -11.05 & -9.43 & -13.05 & $\begin{array}{c}\text { H-bond, salt bridge, } \\
\pi \text {-Interaction, van der } \\
\text { Waals, } \\
\text { Attractive charges }\end{array}$ \\
\hline$\left[\mathrm{Cu}(\text { Lys })(\text { bipy })\left(\mathrm{H}_{2} \mathrm{O}\right)\right]^{2+}$ & -11.04 & -8.72 & -12.23 & $\begin{array}{c}\text { H-bond, salt bridge, } \\
\pi \text {-Interaction, van der } \\
\text { Waals } \\
\text { Attractive charges }\end{array}$ \\
\hline
\end{tabular}

* data from $[83,86,106-108]$.

In Table 4 , the docked binding energies and the interaction with DNA/RNA corresponding to the top molecular pose (lowest energy) for complex ions $\left[\mathrm{Cu}(\mathrm{L}-\mathrm{Gln})(\mathrm{phen})\left(\mathrm{H}_{2} \mathrm{O}\right)\right]^{+}$are shown. As was expected from previous studies, all docked structures occupy similar positions in the minor groove of the 1BNA/DNA and intercalate in the 151D/DNA fragment structures (Figures 7 and 8 ). The compounds interact well with the DNA test molecules, yet considering the binding energies among these complexes, the best affinity energy is found in the complex ion anti-[Cu(L-Gln $)($ phen $\left.)\left(\mathrm{H}_{2} \mathrm{O}\right)\right]^{+}$. Also, it can be implied that ligand phenanthroline has an essential role in the interaction; this result agrees with our previous results $[83,84,86]$. Regarding the interaction with an RNA test molecule (Figure 9), the hydrogen bonds between L-syn and tRNA involve C24, C40, and PSU39 (pseudouridine). Salt bridge interactions involve A38 and G26 and the van der Waals interactions include A29, G42, and U41. On the other hand, L-anti interactions consist of hydrogen bonds with C27 and G26 and van der Waals interactions with C25, C28, A29, U41, G30, PSU39, A38, and 5MC40 (5-methyl-cytosine).

However, the combination of interactions in this study favors the syn-complex. The interactions involve several H-bonds, hydrophobic interactions, salt bridges, attractive charges, and $\pi$-anions, as shown in Figure 10. 
Table 4. Docking results, including the binding energies for the complexes' best molecular poses between DNA and tRNA with the two copper complexes with glutamine.

\begin{tabular}{|c|c|c|}
\hline Compound & $\begin{array}{l}\text { Binding } \\
\text { Energies }(\mathrm{kcal} / \mathrm{mol})\end{array}$ & Interactions \\
\hline \multicolumn{3}{|c|}{ 1BNA } \\
\hline anti-[Cu(L-Gln)(phen) $\left(\mathrm{H}_{2} \mathrm{O}\right]$ & -9.39 & H-bond (3), van der Waals \\
\hline syn- $\left[\mathrm{Cu}(\mathrm{L}-\mathrm{G} \ln )(\mathrm{phen})\left(\mathrm{H}_{2} \mathrm{O}\right]\right.$ & -9.37 & $\begin{array}{l}\text { H-bond (3), van der Waals, } \\
\text { Salt bridge, attractive charge }\end{array}$ \\
\hline \multicolumn{3}{|c|}{ 151D } \\
\hline $\begin{array}{l}\text { anti- }\left[\mathrm{Cu}(\mathrm{L}-\mathrm{Gln})(\text { phen })\left(\mathrm{H}_{2} \mathrm{O}\right]\right. \\
\text { syn- }\left[\mathrm{Cu}(\mathrm{L}-\mathrm{Gln})(\text { phen })\left(\mathrm{H}_{2} \mathrm{O}\right]\right.\end{array}$ & $\begin{array}{l}-8.79 \\
-8.35\end{array}$ & $\begin{array}{l}\text { H-bond (3), van der Waals, } \pi-\pi \\
\text { H-bond (3) van der Waals, } \pi-\pi\end{array}$ \\
\hline \multicolumn{3}{|c|}{ 6TNA } \\
\hline $\begin{array}{l}\text { anti-[Cu(L-Gln)(phen })\left(\mathrm{H}_{2} \mathrm{O}\right] \\
\text { syn- }\left[\mathrm{Cu}(\mathrm{L}-\mathrm{Gln})(\text { phen })\left(\mathrm{H}_{2} \mathrm{O}\right]\right.\end{array}$ & $\begin{array}{l}-9.64 \\
-10.26\end{array}$ & $\begin{array}{c}\text { H-bond (6), van der Waals } \\
\text { H-bond (6), salt bridge, attractive charge, } \pi \text {-anion }\end{array}$ \\
\hline
\end{tabular}
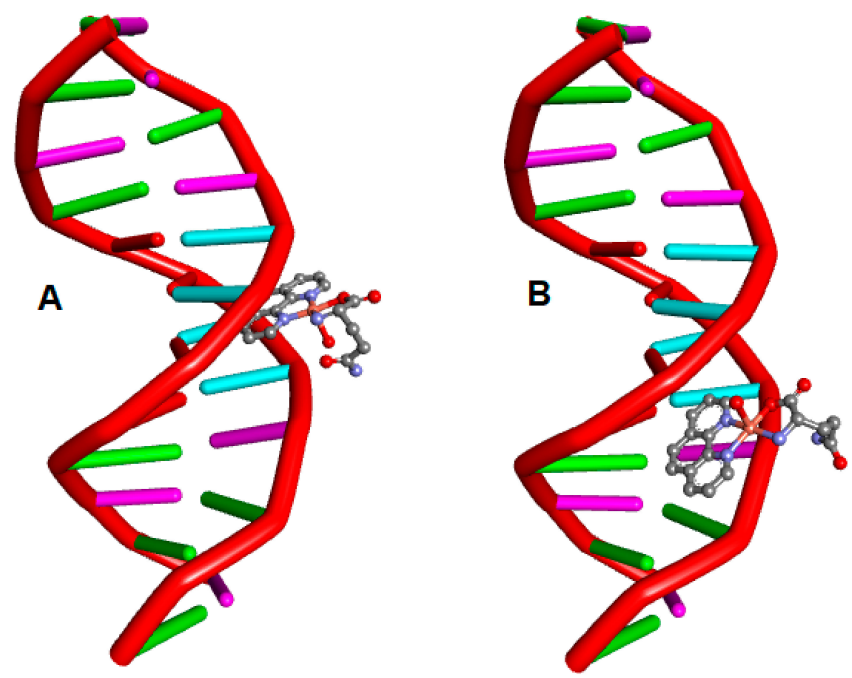

Figure 7. Docked structures of top molecular pose for: (A) anti-[Cu(L-Gln)(phen) $\left(\mathrm{H}_{2} \mathrm{O}\right]-1 \mathrm{BNA}$ and $(\mathbf{B})$ syn- $[\mathrm{Cu}(\mathrm{L}-$ $\mathrm{Gln})($ phen $)\left(\mathrm{H}_{2} \mathrm{O}\right]-1 \mathrm{BNA}$.
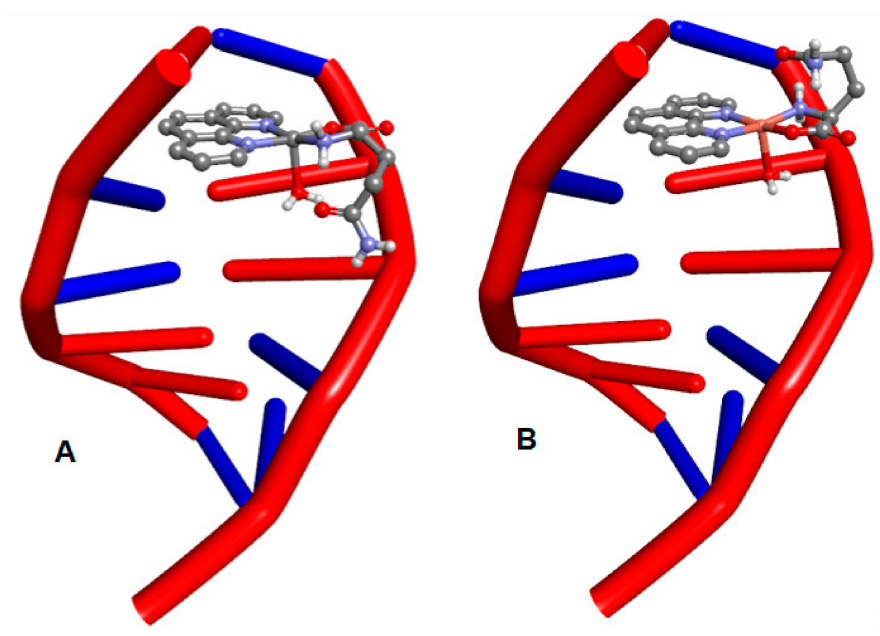

Figure 8. Docked structures of top molecular pose for: (A) anti-[Cu(L-Gln)(phen)( $\left.\mathrm{H}_{2} \mathrm{O}\right]-151 \mathrm{D}$ and $(\mathbf{B})$ syn- $[\mathrm{Cu}(\mathrm{L}-$ $\mathrm{Gln})($ phen $)\left(\mathrm{H}_{2} \mathrm{O}\right]-151 \mathrm{D}$. 

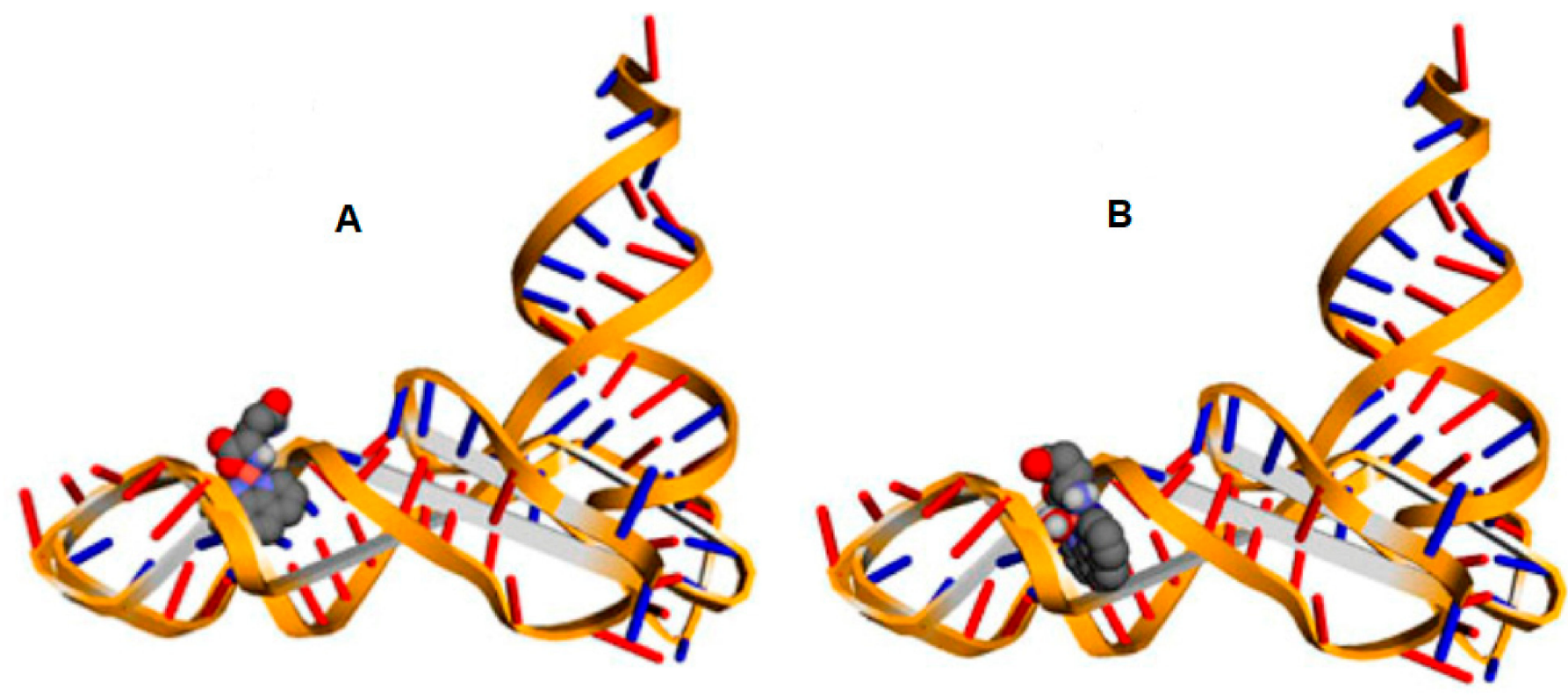

Figure 9. Docked structures of top molecular pose for: (A) anti-[Cu(L-Gln)(phen) $\left(\mathrm{H}_{2} \mathrm{O}\right]-6 \mathrm{TNA}$ and $(\mathbf{B})$ syn- $[\mathrm{Cu}(\mathrm{L}-$ $\mathrm{Gln})(\mathrm{phen})\left(\mathrm{H}_{2} \mathrm{O}\right]-6 \mathrm{TNA}$.
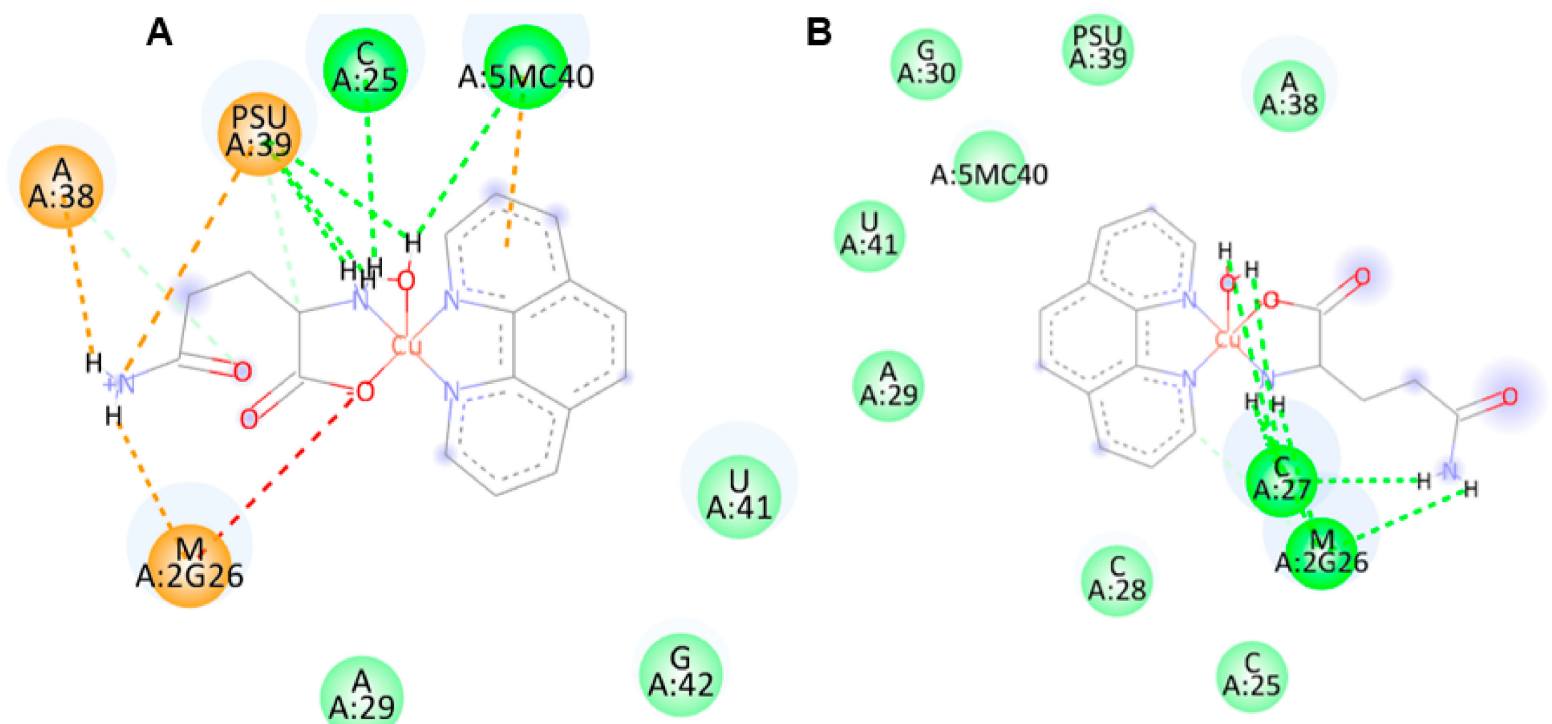

Figure 10. Interactions of Compound 1 and tRNA (6TNA). (A): L-syn and (B): L-anti. The orange dashes represent the attractive charge and the salt bridge interactions. The conventional hydrogen bonds are represented by green dashes, while light green spheres show the van der Waals interactions.

\section{Discussion}

In our search to provide vanadium complexes that mimic the interactions of decavanadates and cyclo-tetravanadates with side-chain groups of proteins with positive or hydrogen-bond donor amino acids, the series of amino acids studied has been expanded to L-glutamine. A new heterobimetallic cyclo-tetravanadate was synthesized and characterized. L-glutamine and phenanthroline mixed copper complex was used to provide potential hydrogen bonds to anchor the complexes of planar di-imines, which are well known to interact with DNA and RNA test molecules [109-111]. Compound 1 crystallizes in the non-centrosymmetric space group P1. Interestingly L-glutamine is present in two 
conformations, where two of the copper complexes show a syn-conformation, while the other two show an anti-conformation.

The existence of $\left[\mathrm{V}_{4} \mathrm{O}_{12}\right]^{4-}$ was confirmed by FTIR spectroscopy analysis, where the characteristics bands are located between $910-1000 \mathrm{~cm}^{-1}$ for asymmetric and symmetric vibrations of terminal $\mathrm{V}\left(\mathrm{O}_{\mathrm{t}}\right)_{2}$. The asymmetric vibrations of the bridge $\mathrm{V}-\mathrm{O}_{\mathrm{b}}-\mathrm{V}$ groups could be allocated to bands below $850 \mathrm{~cm}^{-1}$. It is feasible to establish that cyclo-tetravanadate ions are involved in several hydrogen-bond interactions, causing the usual bands to divide; as a result, there are numerous shoulders, each indicating different $\mathrm{V}\left(\mathrm{O}_{\mathrm{t}}\right)_{2}$ and $\mathrm{V}-\mathrm{O}_{\mathrm{b}}-\mathrm{V}$ vibration strengths. Although second derivative spectra are rare, these are very informative since shoulders end up becoming peaks. On the other hand, the visible spectrum shows an asymmetric absorption band at $\lambda_{\max }$ value $627 \mathrm{~nm}$ because there is the promotion of $\mathrm{d}-\mathrm{d}$ electrons from $\left(\mathrm{d}_{\mathrm{xz}}, \mathrm{d}_{\mathrm{yz}}\right), \mathrm{d}_{\mathrm{xy}}$, and $\mathrm{d}_{\mathrm{z}}{ }^{2}$ to the orbital $\mathrm{d}_{\mathrm{x}}{ }^{2}-\mathrm{y}^{2}$. Therefore, although in solid-state, the geometry corresponds to a square-based pyramid, it may change in aqueous solution to elongated tetragonal octahedron.

Using DFT calculations, the structure was minimized from the crystallographic data, allowing the frontier molecular orbitals and the map of electrostatic potential to be calculated. Global reactivity descriptors, such as chemical potential $(\mu)$, electronegativity $(\chi)$, hardness $(\eta)$, softness $(\mathrm{s})$, and electrophilicity index $(\omega)$, were evaluated based on conceptual DFT approach. The presence of hydrogen bonds dominates all the interactions. Thus an AIM study was conducted to characterize the compound.

It is important to mention that there have only been a few reports on cyclo-tetravanadates: two of them were conducted with organic molecules $\left(\mathrm{C}_{6} \mathrm{H}_{9} \mathrm{~N}_{2}\right)_{4}\left(\mathrm{~V}_{4} \mathrm{O}_{12}\right) \cdot 4 \mathrm{H}_{2} \mathrm{O}$ and $\left[\left(\mathrm{CH}_{3}\right)_{3}-\right.$ $\left.\mathrm{CNH}_{3}\right]_{4}\left(\mathrm{~V}_{4} \mathrm{O}_{12}\right)$ [112,113], vanadium [114,115], iron [116], cobalt [117], nickel [118], zinc $[119,120]$, and $\mathrm{Zr}$ [121]. In the particular case of copper [96,122,123], four complexes have been reported; in all those cases, copper ions were in a trigonal bipyramidal geometry. There have also been also four cyclo-tetravanadates containing three metals [124]. Our group has contributed with $[\mathrm{Cu}(\mathrm{Lys})($ phen $)]-\left(\mathrm{V}_{4} \mathrm{O}_{12}\right)-[\mathrm{Cu}(\mathrm{Lys})($ phen $)],[\mathrm{Cu}(\mathrm{Orn})(\mathrm{bipy})]-$ $\left(\mathrm{V}_{4} \mathrm{O}_{12}\right)-[\mathrm{Cu}(\mathrm{Orn})($ bipy)$)],\left[\mathrm{Cu}(\mathrm{Gly})(\text { phen })\left(\mathrm{H}_{2} \mathrm{O}\right)\right]_{2}[\mathrm{Cu}(\mathrm{Gly})($ phen $)]-\left(\mathrm{V}_{4} \mathrm{O}_{12}\right)-[\mathrm{Cu}(\mathrm{Gly})($ phen $)]$ $[\mathrm{Cu}(\mathrm{Orn})(\mathrm{phen})]-\left(\mathrm{V}_{4} \mathrm{O}_{12}\right)-[\mathrm{Cu}(\mathrm{Orn})($ phen $)]$, and [Cu(Lys)(bipy)]-( $\left(\mathrm{V}_{4} \mathrm{O}_{12}\right)-[\mathrm{Cu}(\mathrm{Lys})($ bipy) $)$, where the cyclo-tetravanadate acts as a bridge and the copper atoms are in a square pyramidal geometry [83-85]. In this paper, we present $\left[\mathrm{Cu}(\mathrm{L}-\mathrm{G} \ln )(\mathrm{phen})\left(\mathrm{H}_{2} \mathrm{O}\right)\right]_{4}\left(\mathrm{~V}_{4} \mathrm{O}_{12}\right)$, the first anionic cyclo-tetravanadate of this type in which the anion is not coordinated to the contraionic copper complexes. Concerning the planarity of the cyclo-tetravanadates, there are many possibilities, ranging from completely flat (D4h symmetry) to Cs symmetry; the compound reported here has Cs symmetry. Although other cyclo-tetravanadates, such as $\left.\left[\mathrm{Fe}(\text { bipy })_{3}\right]_{2}\left[\mathrm{~V}_{4} \mathrm{O}_{12}\right] \cdot 10 \mathrm{H}_{2} \mathrm{O}, \mathrm{Zn}\left(2,2^{\prime} \text {-bipy }\right)_{3}\right]_{2} \mathrm{~V}_{4} \mathrm{O}_{12} \cdot 8 \mathrm{H}_{2} \mathrm{O}$, show uncoordinated $\left(\mathrm{V}_{4} \mathrm{O}_{12}\right)$ anions, we expected a similar structure as our compound with glycinate. However, the introduction of the chiral carbon of the glutamine aminoacidate requires the use of DL-glutamine to surround the cyclo-tetravanadate. Progress has been made in that direction [125]. As pointed out before, the release of the components upon hydrolysis generates active species of vanadium and copper [83-85]. The cationic copper complexes generated have a strikingly similar molecular structure to Casiopeinas ${ }^{\circledR}$ (CAS), a class of copper-based drugs developed by Ruiz-Azuara and colleagues [126-128]. CAS is the first family of antineoplastic copper compounds that have reached the clinical phase in the world [129]. The complexes $\left[\mathrm{Cu}(\mathrm{L}-\mathrm{G} \ln )(\right.$ phen $\left.)\left(\mathrm{H}_{2} \mathrm{O}\right)\right]\left(\mathrm{OClO}_{3}\right)$ and $[\mathrm{Cu}(\mathrm{L}-$ Gln)(bipy) $\left.\left(\mathrm{H}_{2} \mathrm{O}\right) 1 / 2\right]\left(\mathrm{SO}_{4}\right) 1 / 2 \cdot 2 \mathrm{H}_{2} \mathrm{O}$ were synthesized by Patra et al. [130] and represent the cationic part of the compound here reported. Both conformers showed efficient groove binding affinity and "chemical nuclease" activity with DNA. Our docking experiments showed that the cations syn and anti- $\left[\mathrm{Cu}(\mathrm{L}-\mathrm{Gln})(\text { phen })\left(\mathrm{H}_{2} \mathrm{O}\right)\right]^{+}$released by the hydrolysis of the cyclo-tetravanadates can interact with both DNA and RNA test molecules through electrostatic, hydrogen bonds, and hydrophobic interactions. The binding energies of the copper complexes are comparable with well-known compounds with antineoplastic activities, and in the case of RNA, as recently presented by Yunsheng Xu (2019), the closely related Casiopeina II-gly acts on lncRNA MALAT1, a non-coding RNA, thus, opening a 
new mode of action for all related compounds [131]. Recently a paper by Garribba et al. has shown that Cas II-gly binds to low-molecular-mass bioligands found in blood serum (citric, L-lactic acid, and L-histidine) and cytosol (reduced glutathione (GSH), reduced nicotinamide adenine dinucleotide (NADH), adenosine triphosphate (ATP), and L-ascorbic acid). The bioligands replaced glycinato in mixed-species $\mathrm{Cu}^{\mathrm{II}}-\mathrm{Me}_{2}$ phen-bL/cL. The creation of these adducts may aid copper transport to the target organs [132].

Our computational analyses show that several compounds have better binding energies with nucleic acid test molecules than those already in phase 1 clinical trials. It can be observed that the ligand phenanthroline has an essential role in these interactions since it is the moiety that intercalates well into the DNA [133]. On the other hand, when the docking study was carried out considering 6TNA, the binding energies obtained were below $-9.3 \mathrm{kcal} / \mathrm{mol}$. The combination of interactions in this study favors the syn-complex. The interactions involved several $\mathrm{H}$-bond, hydrophobic interactions, salt bridges, attractive charges, and $\pi$-anions. Therefore interactions with tRNA near the anticodon arm are needed to study experimentally in great detail.

\section{Materials and Methods}

\subsection{General Considerations}

The synthesis of Compound 1 was conducted using ammonium metavanadate $\left(\mathrm{NH}_{4} \mathrm{VO}_{3}\right)$, L-glutamine, and 1,10-phenanthroline hydrochloride (phen) purchased from Merck Mexico. $\mathrm{KOH}$ was purchased from Fermont, and $\mathrm{CuCl}_{2} \cdot 2 \mathrm{H}_{2} \mathrm{O}$ was purchased from Química Dinámica S. A. de C. V, Nuevo Leon, Mexico. All manipulations were conducted without specific purification of solvents and reagents. The complexes' electronic spectra were determined by UV-Vis spectroscopy with a xenon lamp Varian Cary 50 spectrophotometer(Varian, Palo Alto, CA, USA) and using a quartz cuvette of $1 \mathrm{~cm}$ path length. The infrared spectrum was obtained from 500 to $4000 \mathrm{~cm}^{-1}$ in $\mathrm{KBr}$ pellets using an IR Digilab, Mod. Scimitar Spectrophotometer with FTIR (Digilab, Hopkinton, MA, USA).

\subsection{Crystallization and Synthesis}

Compound 1 was prepared by adding $1.00 \times 10^{-3} \mathrm{~mol}(0.198 \mathrm{~g})$ of 1,10 -phenanthroline hydrochloride to $30 \mathrm{~mL}$ distilled water with stirring and moderate heat; once dissolved, $1.00 \times 10^{-3} \mathrm{~mol}(0.170 \mathrm{~g})$ of $\mathrm{CuCl}_{2} \cdot 2 \mathrm{H}_{2} \mathrm{O}$ was added, and the clear solution was adjusted to $\mathrm{pH} 9.5$ by slow addition of (10 percent) $\mathrm{KOH}$ solution. Subsequently, when a clear blue solution was achieved, $2.00 \times 10^{-3} \mathrm{~mol}$ of L-glutamine were added while stirring. Then, $\mathrm{NH}_{4} \mathrm{VO}_{3}, 1.00 \times 10^{-3} \mathrm{~mol}(0.116 \mathrm{~g})$ in $15 \mathrm{~mL} \mathrm{H} \mathrm{H}_{2} \mathrm{O}$, was added dropwise to the solution. The final $\mathrm{pH}$ at room temperature was 9 . The solution was filtered and left at room temperature. Blue prismatic crystals were recovered by filtration after six days.

\subsection{Single Crystal X-ray Diffraction}

Single crystal of $\left[\mathrm{Cu}(\mathrm{L}-\mathrm{Gln})(\text { phen })\left(\mathrm{H}_{2} \mathrm{O}\right)\right]_{4}\left[\mathrm{~V}_{4} \mathrm{O}_{12}\right] \cdot\left(\mathrm{H}_{2} \mathrm{O}\right)_{8}$ (Compound 1), suitable for $\mathrm{X}$-ray diffraction, was selected and mounted on an Xcalibur, Atlas, Gemini diffractometer. The crystal was kept at $293.15 \mathrm{~K}$ during data collection. Using Olex2 [134], the structure was solved with the SHELXD [135] structure solution program using dual space and refined with the SHELXL [136] refinement package using least squares minimization. Compound 1 crystallizes in the triclinic space group P1, with only one asymmetric unit filling the unit cell. Figure 1 shows the complete molecule crystal data. Selected crystal data and details are shown in Table 1 and Tables S1-S5 for the compound's structure determination. The CCDC number is 2,081,603 (Compound 1). Additional crystallographic data for this paper are presented in the Supplementary Materials. You can obtain complete data free of charge from http:/ / www.ccdc.cam.ac.uk/conts/re-trieving.html (accessed on 15 May 2021) (or CCDC, 12 Union Road, Cambridge CB2 1EZ, UK; Fax: +44-1223-336-033; e-mail: deposit@ccdc.cam.ac.uk). Using Mercury CSD (release 4.3.1) [87]. 


\subsection{Computational Methods}

Molecular structure, frontier molecular orbitals (FMO), and molecular electrostatic potential (MEP) of Compound 1 was carried out using the hybrid functional B3LYP [137], including the empirical dispersion method of Grimme with Becke-Johnson damping, GD3BJ [138]. The double zeta split-valence Def2SVP basis set [139] for C, H, O, and N atoms and LanL2DZ basis set [140] for $\mathrm{Cu}$ and $\mathrm{V}$ atoms were used. In addition, LanL2DZ was used as an effective core potential (ECP) for $\mathrm{Cu}$ and V atoms [141]. The effect of the implicit solvation was included with the polarizable continuum model (PCM), using the integral equation formalism variant (IEFPCM) with water as the solvent [142]. Calculations were performed with the Gaussian16 and GaussView programs $[143,144]$. Global reactivity descriptors were calculated from the FMO energies based on the conceptual DFT approach [145]. Atoms in molecules analysis (AIM) using AIMAll software (Version 14.11.23, TK Gristmill Software, Cambridge, MA, USA) was performed for analyzing the non-covalent interactions [146].

\subsection{Molecular Docking}

Molecular docking analysis was performed with the semi-flexible method. The DNA fragments used were Dickerson-Drew dodecamer (DDD) with the sequence $\mathrm{d}$ (CGCGAATTCGCG) (PDB ID: 1BNA [147]) and DNA fragment with the sequence $\mathrm{d}(C G A T C G)$ (PDB ID:151D [148]. The RNA docking was carried out using the yeast tRNA (PDB: 6TNA) [149] and considered a rigid entity. Complete flexibility was allowed for the coordination compounds [150], and it was performed using the Autodock Tools 1.5.6 software (accessed on 1 September 2021) [151], which includes the addition of polar hydrogens and empirical particles of atomic charges (Gasteiger-Marsili method). A grid box that encloses the entire DNA fragment was used with sizes 70, 70, and $120 \AA$ for the 1BNA DNA fragment and 60, 60, and $76 \AA$ for the 151D DNA fragment. For tRNA, blind docking was carried out using three different boxes that enclosed the entire tRNA with the sizes $96,80,108 \AA$, followed by a re-docking of the compounds in their docked pose with potential and preferred minimized energy using a box centered on the compounds with the sizes 40,40 , and $40 \AA$. The grid spacing for all the docking calculations was set to the 0.375 $\AA$ default value, using the Lamarckian genetic algorithm (LGA) searching methods. The parameters for the copper atom were the sum of VDW radii of two similar atoms (3.50 $\AA$ ), plus the VDW well depth $(0.005 \mathrm{kcal} / \mathrm{mol})$, plus the atomic solvation volume (12.0 $\mathrm{A} 3)$, plus the atomic solvation parameter $(-0.00110)$. The $\mathrm{H}$-bond radius of the heteroatom in contact with hydrogen $(0.0 \AA)$, the well depth of the H-bond $(0.0 \mathrm{kcal} / \mathrm{mol})$, and different integers showed the type of $\mathrm{H}$-bonding atom and indexes for the generation of the auto grid map $(0,-1,-1,1$, respectively). The corresponding figures were prepared using Biovia Discovery Studio [152].

\section{Conclusions}

A new $\mathrm{V} / \mathrm{Cu}$ heterobimetallic compound was synthesized and characterized by visible and FTIR spectroscopies. Compound $\mathbf{1}$ crystallizes in the triclinic $\mathbf{P 1}$ space group with the cyclo-tetravanadate anion acting as a free ion, only bound to the copper moieties through hydrogen bonds and water molecules. The cyclo-tetravanadate anion provides a hydrogenbonded bridge between two conformers syn and two anti of the [Cu(L-Gln)(phen) $\left.\left(\mathrm{H}_{2} \mathrm{O}\right)\right]$ cationic complexes. The cyclo-tetravanadate is not coordinated to the copper, and thus, it can be easily separated in an aqueous solution to act independently. The AIM analysis indicated that the hydrogen-bond interactions govern the structural arrangement in the compound. Additionally, the $\mathrm{Cu}-\mathrm{O}$ interactions (between $\mathrm{Cu}$ with $\mathrm{O}$ of apical water or with $\mathrm{O}$ of cyclo-tetravanadate) have high interaction energy values, indicating that they are responsible for the supramolecular arrangement. Also, the hydrogen bonds surrounding the cyclo-tetravanadate could serve as models for the interaction of side-chain hydrogen bond donors in hydrophilic pockets in proteins. 
The copper moieties are reminiscent of Casiopeinas IIa y IIIia, which are in phase I clinical trials in Mexico. Docking studies indicated that both compounds can interact with DNA and RNA test molecules, acting as groove binders and intercalating agents. It is important to point out that a combination of electrostatic and hydrophobic interactions, $\pi-\pi$, and hydrogen bonds, are responsible for binding DNA/RNA molecules. The energies of interaction are comparable with other well-known and proven agents with anticancer activities. The binding energies of the RNA interactions are more favorable than other compounds already reported and point to RNA potential metallodrugs, which has become relevant as an easy-to-reach target since other important RNA molecules have been discovered to be involved in specific cancers [153]. The recently explored direct injection into the tumors or the encapsulation in liposomes or nisomes opens an excellent opportunity to improve the potential antitumor activities of the compound here presented. The recent reports in cancer therapy and the new strategies for delivering vanadium and copper point to significant advances in the near future.

Supplementary Materials: The following are available online at https:/ /www.mdpi.com/article/

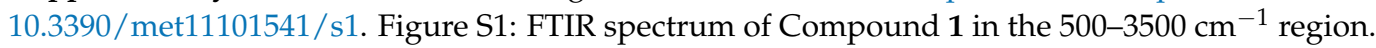
Figure S2: The visible spectrum of Compound 1. Crystallographic data are presented in Tables S1-S5. Topological parameters (a.u.), interaction energies EH ... Y $\left(\mathrm{kcal} \mathrm{mol}^{-1}\right)$, and interatomic distances Dint $(\AA)$ are presented in Table S6. The check CIF of Compound $\mathbf{1}$ is also included in the Supplementary Materials.

Author Contributions: N.D.C.-M. and B.M.-V. carried out experimental work (synthesis, crystallization, and experimental characterization). F.J.M.-B., M.E.C. and L.N. carried out the theoretical characterization. A.M. carried out the X-ray diffraction determination. E.G.-V., M.E.C. and B.L.S.-G. wrote and revised the manuscript. N.D.C.-M. and E.G.-V. conceived and designed this study. All authors contributed extensively to the work presented in this paper. All authors have read and agreed to the published version of the manuscript.

Funding: Projects funded this research: 100517029-VIEP, 100233622-VIEP, SEP PRODEP BUAPPTC_617, and the PRODEP Academic Group BUAP-CA-263 (SEP, Mexico).

Institutional Review Board Statement: Not applicable.

Informed Consent Statement: Not applicable.

Data Availability Statement: Data is contained within the article or Supplementary Materials.

Acknowledgments: Nidia D. Corona Motolinia, Beatriz Martínez Valencia, and Lisset Noriega wish to thank CONACyT (Mexico) Ph.D. fellowship support numbers 390894, 593307, and 697889. María Eugenia Castro and Francisco J. Melendéz wish to thank Laboratorio Nacional de Supercómputo del Sureste de México (LNS-BUAP) and the CONACyT network of national laboratories for the computer resources and support provided. We also thank Angel Mendoza, who carried out the X-ray diffraction experiment. B.L.S-G thanks the grant SEP PRODEP BUAP-PTC_617. We thank the support provided by VIEP-BUAP through Yadira Rosas Bravo for observations and comments to improve this manuscript.

Conflicts of Interest: There is no conflict of interest to declare.

\section{References}

1. Anthony, E.J.; Bolitho, E.M.; Bridgewater, H.E.; Carter, O.W.L.; Donnelly, J.M.; Imberti, C.; Lant, E.C.; Lermyte, F.; Needham, R.J.; Palau, M.; et al. Metallodrugs are unique: Opportunities and challenges of discovery and development. Chem. Sci. 2020, 11, 12888. [CrossRef] [PubMed]

2. Li, S.; Chen, Y.; Zhu, W.; Yang, W.; Chen, Z.; Song, J.; Song, X.; Chen, X.; Yang, H. Engineered Nanoscale Vanadium Metallodrugs for Robust Tumor-Specific Imaging and Therapy. Adv. Funct. Mater. 2021, 31, 2010337. [CrossRef]

3. Sung, H.; Ferlay, J.; Siegel, R.L.; Laversanne, M.; Soerjomataram, I.; Jemal, A.; Bray, F. Global Cancer Statistics 2020: GLOBOCAN Estimates of Incidence and Mortality Worldwide for 36 Cancers in 185 Countries. CA Cancer J. Clin. 2021, 71, 209-249. [CrossRef] [PubMed]

4. OPS/OMS, Programa de Cáncer. Available online: https://www.paho.org/es/campanas/dia-mundial-contra-cancer-2021-yosoy-voy (accessed on 24 September 2021). 
5. Spreckelmeyer, S.; Orvig, C.; Casini, A. Cellular transport mechanisms of cytotoxic metallodrugs: An overview beyond cisplatin. Molecules 2014, 19, 15584-15610. [CrossRef]

6. Ndagi, U.; Ndumiso, M.; Mahmoud, E.S. Metal complexes in cancer therapy-An update from drug design perspective. Drug Des. Dev. Ther. 2017, 11, 599-616. [CrossRef]

7. Ghosh, S. Cisplatin: The first metal based anticancer drug. Bioorg. Chem. 2019, 88, 102925. [CrossRef]

8. Wheate, N.J.; Walker, S.; Craig, G.E.; Oun, R. The Status of Platinum Anticancer Drugs in the Clinic and in Clinical Trials. Dalton Trans. 2010, 39, 8113-8127. [CrossRef]

9. Valdéz-Camacho, J.R.; Ramírez-Solís, A.; Escalante, J.; Ruiz-Azuara, L.; Ho, M. Theoretical determination of half-wave potentials for phenanthroline-, bipyridine-, acetylacetonate-, and glycinate-containing copper (II) complexes. J. Mol. Model. 2020, $26,191$. [CrossRef]

10. Krajčiová, D.; Melník, M.; Havránek, E.; Forgácsová, A.; Mikuš, P. Copper compounds in nuclear medicine and oncology. J. Coord. Chem. 2014, 67, 1493-1519. [CrossRef]

11. Ruiz-Azuara, L.; Bravo-Gómez, M.E. Copper Compounds in Cancer Chemotherapy. Curr. Med. Chem. 2010, 17, 3606-3615. [CrossRef]

12. Denoyer, D.; Clatworthy, S.A.S.; Cater, M.A. Copper Complexes in Cancer Therapy. Met. Ions Life Sci. 2018, 18, 469-506. [CrossRef]

13. Dhakshanamoorthy, S.; Krishnan, M.M.; Arumugham, M.N. Synthesis, characterization, DNA binding/cleavage, anticancer and antimicrobial activity of ternary copper(II) complexes. Asian J. Res. Chem. 2017, 10, 312-318. [CrossRef]

14. Ezhilarasan, D.; Arumugham, M.N. Synthesis, characterization DNA binding and biological activity of Copper(II) complexes with mixed ligands. J. Chem. Biol. Phys. Sci. 2017, 7, 896-905.

15. Tabti, R.; Tounsi, N.; Gaiddon, C.; Bentouhami, E.; Désaubry, L. Progress in Copper Complexes as Anticancer Agents. Med. Chem. 2017, 7, 875-879. [CrossRef]

16. İnci, D.; Aydin, R. A review of DNA binding activities of metal (II) complexes containing aromatic amino acids and intercalating ligands. In Natural Sciences: Methods and Applications; Iksad Publishing House: Ankara, Turkey, 2021; Volume 89, Chapter 4.

17. Sigman, D.S.; Graham, D.R.; Aurora, V.D.; Stern, A.M. Oxygen-dependent cleavage of DNA by the 1,10-phenanthroline cuprous complex. Inhibition of Escherichia coli DNA polymerase I. J. Biol. Chem. 1979, 254, 12269-12272. [CrossRef]

18. Mancin, F.; Scrimin, P.; Tecilla, P.; Tonellato, U. Artificial metallonucleases. Chem. Commun. 2005, 20, 2540-2548. [CrossRef] [PubMed]

19. Morrow, J.R.; Iranzo, O. Synthetic metallonucleases for RNA cleavage. Curr. Opin. Chem. Biol. 2004, 8, 192-200. [CrossRef] [PubMed]

20. Mancin, F.; Scrimin, P.; Tecilla, P. Progress in artificial metallonucleases. Chem. Commun. 2012, 48, 5545-5559. [CrossRef] [PubMed]

21. McGivenrn, T.J.P.; Marmion, A.C.J. Copper complexes as artificial DNA metallonucleases: From Sigman's reagent to a nextgeneration anticancer agent? Inorg. Chim. Acta 2018, 472, 12-39. [CrossRef]

22. Dupureur, C.M. An Integrated Look at Metallonuclease Mechanism. Curr. Chem. Biol. 2008, 2, 159-173.

23. Yu, Z.; Cowan, J.A. Metal complexes promoting catalytic cleavage of nucleic acids-Biochemical tools and therapeutics. Curr. Opin. Chem. Biol. 2018, 43, 37-42. [CrossRef] [PubMed]

24. Mukherjee, D.; Das, R.K. DNA Cleavage by Transition Metal Complexes and its Applications-A Review. Int. J. Pharm. Biol. Sci. 2019, 9, 1089-1106.

25. Williams, D.E.; Grant, K.B. Metal-Assisted Hydrolysis Reactions Involving Lipids: A Review. Front. Chem. 2019, 7, 14. [CrossRef]

26. Lüdtke, C.; Sobottka, S.; Heinrich, J.; Liebing, P.; Wedepohl, S.; Sarkar, B.; Kulak, N. Forty Years after the Discovery of Its Nucleolytic Activity: $\left[\mathrm{Cu}(\text { phen })_{2}\right]^{2+}$ Shows Unattended DNA Cleavage Activity upon Fluorination. Chem.-Eur. J. 2020, 27, 3273-3277. [CrossRef]

27. Zhang, Z.; Wang, H.; Yan, M.; Wang, H.; Zhang, C. Novel copper complexes as potential proteasome inhibitors for cancer treatment (Review). Mol. Med. Rep. 2017, 15, 3-11. [CrossRef] [PubMed]

28. Molinaro, C.; Martoniati, A.; Pelinski, L.; Cailliau, K. Phenanthroline-Cu(II) complexes modulated by amino acids can induce cancer cell apoptosis via mitochondrial signaling. Cancers 2020, 12, 2863. [CrossRef] [PubMed]

29. Badea, M.; Uivarosi, V.; Olar, R. Improvement in the Pharmacological Profile of Copper Biological Active Complexes by Their Incorporation into Organic or Inorganic Matrix. Molecules 2020, 25, 5830. [CrossRef]

30. Zehra, S.; Tabassum, S.; Arjmand, F. Biochemical pathways of copper complexes: Progress over the past 5 years. Drug Discov. Today 2021, 26, 1086-1096. [CrossRef]

31. Erxleben, A. Interactions of copper complexes with nucleic acids. Coord. Chem. Rev. 2018, 360, 92-121. [CrossRef]

32. Iakovidis, I.; Delimaris, I.; Piperakis, S.M. Copper and Its Complexes in Medicine: A Biochemical Approach. Mol. Biol. Int. 2011, 2011, 594529. [CrossRef]

33. Denoyer, D.; Masaldan, S.; La Fontaine, S.; Cater, M.A. Targeting copper in cancer therapy: 'Copper That Cancer'. Metallomics 2015, 7, 1459-1476. [CrossRef]

34. Duncan, C.; White, A.R. Copper complexes as therapeutic agents. Metallomics 2012, 4, 127-138. [CrossRef]

35. Zhou, M.; Tian, M.; Li, C. Copper-Based Nanomaterials for Cancer Imaging and Therapy. Bioconjug. Chem. 2016, 27, 1188-1199. [CrossRef]

36. Ng, C.H.; Kong, S.M.; Tiong, Y.L.; Maah, M.J.; Sukram, N.; Ahmad, M.; Khoo, A.S.B. Selective anticancer copper(II)-mixed ligand complexes: Targeting of ROS and proteasomes. Metallomics 2014, 6, 892-906. [CrossRef] 
37. Alvarez, N.; Viña, D.; Leite, C.M.; Mendes, L.F.S.; Batista, A.A.; Ellena, J.; Costa-Filho, A.; Facchin, G. Synthesis and structural characterization of a series of ternary copper(II)-L-dipeptide-neocuproine complexes. Study of their cytotoxicity against cancer cells including MDA-MB-231, triple-negative breast cancer cells. J. Inorg. Biochem. 2019, 203, 110930. [CrossRef]

38. Mroueh, M.; Daher, C.; Hariri, E.; Demirdjian, S.; Isber, S.; Choi, E.S.; Mirtamizdoust, B.; Hammud, H.H. Magnetic property, DFT calculation, and biological activity of bis[( $\mu$ (2)-chloro)chloro(1,10-phenanthroline)copper(II)] complex. Chem.-Biol. Interact. 2015, 231, 53-60. [CrossRef]

39. Miranda-Calderón, J.E.; Macías-Rosales, L.; Gracia-Mora, I.; Ruíz-Azuara, L.; Faustino-Vega, A.; Gracia-Mora, J.; Bernad-Bernad, M.J. Effect of casiopein III-ia loaded into chitosan nanoparticles on tumor growth inhibition. J. Drug Deliv. Sci. Technol. 2018, 48, 1-8. [CrossRef]

40. Reina, M.; Hernández-Ayala, L.F.; Bravo-Gómez, M.E.; Gómez, V.; Ruiz-Azuara, L. Second generation of Casiopeinas®: A joint experimental and theoretical study. Inorg. Chim. Acta 2021, 517, 120201. [CrossRef]

41. Oliveira, J.A.; Gomes, J.; Oliveira da Silva, A.; Ayala, A.P.; Santos-Oliveira, R.; Silva, A.; Ferreira, F. Copper(II):phenanthroline complexes with L-asparagine and L-methionine: Synthesis, crystal structure and in-vitro cytotoxic effects on prostate, breast, and melanoma cancer cells. Polyhedron 2020, 191, 114807.

42. Zhang, S.; Chun, X.; Chen, Y.; Zhou, J. Synthesis, Crystal Structure and DNA Cleavage Activity of a Ternary Copper(II) Complex of Dipyrido[3,2-d:2', 3'-f]-quinoxaline and Glycine. Chin. J. Chem. 2011, 29, 65-71. [CrossRef]

43. Nakahata, D.H.; De Paiva, R.E.F.; Lustri, W.R.; Ribeiro, C.M.; Pavan, F.R.; Da Silva, G.G.; Ruiz, A.L.T.G.; De Carvalho, J.E.; Corbi, P.P. Sulfonamide-containing copper(II) metallonucleases: Correlations with in vitro antimycobacterial and antiproliferative activities. J. Inorg. Biochem. 2018, 187, 85-96. [CrossRef] [PubMed]

44. Ruiz Azuara, L.; Fuentes Noriega, I.; Espinoza Guillén, A.; García Conde, D.; Cortés Guzmán, F. Composición Parental de Casiopeína y Sus Usos de la Misma; Gaceta Digital del Instituto de Química UNAM: México City, Mexico, 2017.

45. Krasnovskaya, O.; Naumov, A.; Guk, D.; Gorelkin, P.; Erofeev, A.; Beloglazkina, E.; Majouga, A. Copper Coordination Compounds as Biologically Active Agents. Int. J. Mol. Sci. 2020, 21, 3965. [CrossRef]

46. Treviño, S.; Díaz, A.; Sánchez-Lara, E.; Sanchez-Gaytan, B.L.; Perez-Aguilar, J.M.; González-Vergara, E. Vanadium in Biological Action: Chemical, Pharmacological Aspects, and Metabolic Implications in Diabetes Mellitus. Biol. Trace Elem. Res. 2019, 188, 68-98. [CrossRef] [PubMed]

47. Treviño, S.; González-Vergara, E. Metformin-decavanadate treatment ameliorates hyperglycemia and redox balance of the liver and muscle in a rat model of alloxan-induced Diabetes. New J. Chem. 2019, 43, 17850-17862. [CrossRef]

48. Crans, D.C.; Henry, L.; Cardiff, G.; Posner, B.I. Developing vanadium as an antidiabetic or anticancer drug: A clinical and historical perspective. Met. Ions Life Sci. 2019, 19, 203-230.

49. Aureliano, M. The role of decavanadate in antitumor activity. Glob. J Cancer Ther. 2017, 3, 012-014. [CrossRef]

50. Kowalski, S.; Wyrzykowski, D.; Inkielewicz-Stepniak, I. Molecular and Cellular Mechanisms of Cytotoxic Activity of Vanadium Compounds against Cancer Cells. Molecules 2020, 25, 1757. [CrossRef]

51. Costa Pessoa, J.; Etcheverry, S.; Gambino, D. Vanadium compounds in medicine. Coord. Chem. Rev. 2015, 301, 24-48. [CrossRef]

52. Lu, L.-P.; Suo, F.-Z.; Feng, Y.-L.; Song, L.-L.; Li, Y.; Li, Y.-J.; Wang, K.-T. Synthesis and biological evaluation of vanadium complex as novel antitumor agents. Eur. J. Med. Chem. 2019, 176, 1-10. [CrossRef]

53. Griffin, E.; Levina, A.; Lay, P.A. Vanadium(V) tris-3,5-di-tert-butylcatecholato complex: Links between speciation and antiproliferative activity in human pancreatic cancer cells. J. Inorg. Biochem. 2019, 201, 110815. [CrossRef] [PubMed]

54. Pisano, M.; Arru, C.; Serra, M.; Galleri, G.; Sanna, D.; Garribba, E.; Palmieri, G.; Rozzo, C. Antiproliferative activity of vanadium compounds: Effects on the major malignant melanoma molecular pathways. Metallomics 2019, 11, 1687-1699. [CrossRef] [PubMed]

55. Levina, A.; Vieira, A.P.; Wijetunga, A.; Kaur, R.; Koehn, J.T.; Crans, D.C.; Lay, P.A. A Short-Lived but Highly Cytotoxic Vanadium(V)Complex as a Potential Drug Lead for Brain Cancer Treatment by Intratumoral Injections. Angew. Chem. 2020, 132, 15968-15972. [CrossRef]

56. León, I.L.; Ruiz, M.C.; Franca, C.A.; Parajón-Costa, B.S.; Baran, E.J. Metvan, bis(4,7-Dimethyl-1,10-phenanthroline) sulfatooxidovanadium(IV): DFT and Spectroscopic Study-Antitumor Action on Human Bone and Colorectal Cancer Cell Lines. Biol. Trace Elem. Res. 2019, 191, 81-87. [CrossRef]

57. Althumairy, D.; Postal, K.; Barisas, B.G.; Nunes, G.G.; Roess, D.A.; Crans, D.C. Polyoxometalates function as indirect activators of a G protein-coupled receptor. Metallomics 2020, 12, 1044-1061. [CrossRef]

58. Althumairy, D.; Murakami, H.A.; Zhang, D.; Barisas, B.G.; Roess, D.A.; Crans, D.C. Effects of vanadium(IV) compounds on plasma membrane lipids lead to $G$ protein-coupled receptor signal transduction. J. Inorg. Biochem. 2020, 203, 110873. [CrossRef] [PubMed]

59. Yang, C.; Yu, H.; Gao, Y.; Guo, W.; Li, Z.; Chen, Y.; Pan, Q.; Ren, M.; Han, X.; Guo, C. Surface-engineered vanadium nitride nanosheets for an imaging-guided photothermal/photodynamic platform of cancer treatment. Nanoscale 2019, 11, 1968-1977. [CrossRef] [PubMed]

60. Chen, T.; Huang, R.T.; Liang, J.; Zhou, B.; Guo, X.; Shen, X.C.; Jiang, B.P. Natural Polyphenol-vanadium Oxide Nanozymes for Synergistic Chemodynamic/Photothermal Therapy. Chem. Eur. J. 2020, 26, 15159. [CrossRef] [PubMed]

61. Kioseoglou, E.; Petanidis, S.; Gabriel, C.; Salifoglou, A. The chemistry and biology of vanadium compounds in cancer therapeutics. Coordination. Coord. Chem. Rev. 2015, 301-302, 87-105. [CrossRef] 
62. Costa Pessoa, J.; Santos, M.F.A.; Correia, I.; Sanna, D.; Sciortino, G.; Garriba, E. Binding of vanadium ions and complexes to proteins and enzymes in aqueous solution. Coord. Chem. Rev. 2021, 449, 214192. [CrossRef]

63. Crans, D.C.; Yang, L.; Haase, A.; Yang, X. Health Benefits of Vanadium and Its Potential as an Anticancer Agent. Met. Ions Life Sci. 2018, 18, 251-279.

64. Redher, D. The potentiality of vanadium in medicinal applications. Inorg. Chim. Acta 2020, 504, 119445.

65. Alves de Lima, L.M.; Da Silva, A.K.J.; De Mendonca, T.F.; Da Silva, J.P.; Moura, S.V.N.; Batista, E.K.; Lira, E.C.; Belian, M.F. "Redescobrindo e redesenhando" estratégias para obtenção de complexos de vanádio com atividade anti-diabética. Rev. Virtual Quim. 2021, 13, 933-952. [CrossRef]

66. Samart, N.; Althumairy, D.; Zhang, D.; Roess, D.; Crans, D.C. Initiation of a novel mode of membrane signaling: Vanadium facilitated signal transduction. Coord. Chem. Rev. 2020, 416, 213286. [CrossRef]

67. Lima, L.M.A.; Murakami, H.; Gaebler, D.J.; Silva, W.E.; Belian, M.F.; Lira, E.C.; Crans, D.C. Acute Toxicity Evaluation of Non-Innocent Oxidovanadium(V) Schiff Base Complex. Inorganics 2021, 9, 42. [CrossRef]

68. Sánchez-Lara, E.; Treviño, S.; Sánchez-Gaytán, B.L.; Sáchez-Mora, E.; Castro, M.E.; Meléndez-Bustamante, F.J.; Méndez-Rojas, M.A.; González-Vergara, E. Decavanadate Salts of Cytosine and Metformin: A Combined Experimental-Theoretical Study of Potential Metallodrugs against Diabetes and Cancer. Front. Chem. 2018, 6, 402. [CrossRef]

69. Cheng, M.; Li, N.; Hu, N.W.K.; Xiao, Z.; Wu, P.; Wei, Y. Synthesis, structure and antitumor studies of a novel decavanadate complex with a wavelike two-dimensional network. Polyhedron 2018, 155, 313-319. [CrossRef]

70. Silva-Nolasco, A.M.; Camacho, L.; Saavedra-Díaz, R.O.; Hernández-Abreu, O.; León, I.E.; Sánchez-Lombardo, I. Kinetic Studies of Sodium and Metforminium Decavanadates Decomposition and In Vitro Cytotoxicity and Insulin-Like Activity. Inorganics 2020, 8, 67. [CrossRef]

71. Ksiksi, R.; Abdelkafi-Koubaa, Z.; Mlayah-Bellalouna, S.; Aissaoui, D.; Marrakchi, N.; Srairi-Abid, N.; Zid, M.F.; Graia, M. Synthesis, structural characterization and antitumoral activity of $\left(\mathrm{NH}_{4}\right)_{4} \mathrm{Li}_{2} \mathrm{~V}_{10} \mathrm{O}_{28} \cdot 10 \mathrm{H}_{2} \mathrm{O}$ compound. J. Mol. Struct. 2021, 1229, 129492. [CrossRef]

72. Louati, M.; Ksiksi, R.; Elbini-Dhouib, I.; Mlayah-Bellalouna, S.; Doghri, R.; Srairi-Abid, N.; Zid, M.-F. Synthesis, structure, and characterization of a novel decavanadate, $\mathrm{Mg}\left(\mathrm{H}_{2} \mathrm{O}\right)_{6}\left(\mathrm{C}_{4} \mathrm{~N}_{2} \mathrm{H}_{7}\right)_{4} \mathrm{~V}_{10} \mathrm{O}_{28} \cdot 4 \mathrm{H}_{2} \mathrm{O}$. J. Mol. Struct. 2021, 1242, 130711. [CrossRef]

73. Irving, E.; Tagalakis, A.D.; Maeshima, R.; Hart, S.L.; Eaton, S.; Lehtonen, A.; Stoker, A.W. The liposomal delivery of hydrophobic oxidovanadium complexes imparts highly effective cytotoxicity and differentiating capacity in neuroblastoma tumor cells. Sci. Rep. 2020, 10, 16660. [CrossRef]

74. Halevas, E.; Mavroidi, B.; Swanson, C.H.; Smith, G.C.; Moschona, A.; Hadjispyrou, S.; Salifoglou, A.; Pantazaki, A.A.; Pelecanou, M.; Litsardakis, G. Magnetic cationic liposomal nanocarriers for the efficient drug delivery of a curcumin-based vanadium complex with anticancer potential. J. Inorg. Biochem. 2019, 199, 110778. [CrossRef]

75. Amante, C.; Sousa-Coelho, D.; Luísa, A.; Aureliano, M. Vanadium and Melanoma: A Systematic Review. Metals 2021, 11, 828. [CrossRef]

76. Correia, I.; Borovic, S.; Cavaco, I.; Matos, C.P.; Roy, S.; Santos, H.M.; Fernandes, L.; Capelo, J.L.; Ruiz-Azuara, L.; Costa Pessoa, J. Evaluation of the binding of four anti-tumor Casiopeínas®to human serum albumin. J. Inorg. Biochem. 2017, 175, 284-297. [CrossRef]

77. Nunes, P.; Correia, I.; Cavaco, I.; Marques, F.; Pinheiro, T.; Avecilla, F.; Costa Pessoa, J. Therapeutic potential of vanadium complexes with 1, 10-phenanthroline ligands, quo vadis? Fate of complexes in cell media and cancer cells. J. Inorg. Biochem. 2021, 217, 111350. [CrossRef] [PubMed]

78. Levina, A.; Lay, P.A. Stabilities and Biological Activities of Vanadium Drugs: What is the Nature of the Active Species? Chem. Asian J. 2017, 12, 1692-1699. [CrossRef] [PubMed]

79. Levina, A.; Crans, D.C.; Lay, P.A. Speciation of metal drugs, supplements, and toxins in media and bodily fluids control in vitro activities. Coord. Chem. Rev. 2017, 352, 473-498. [CrossRef]

80. Levina, A.; Lay, P.A. Vanadium (V/IV)-Transferrin Binding Disrupts the Transferrin Cycle and Reduces Vanadium Uptake and Antiproliferative Activity in Human Lung Cancer Cells. Inorganic Chemistry 2020, 59, 16143-16153. [CrossRef] [PubMed]

81. Sciortino, G.; Maréchal, J.D.; Garribba, E. Integrated approaches to characterize the systems formed by vanadium with proteins and enzymes. Inorg. Chem. Front. 2021, 8, 1951-1974. [CrossRef]

82. Aureliano, M.; Gumerova, N.I.; Sciortino, G.; Garribba, E.; Rompel, A.; Crans, D.C. Polyoxovanadates with emerging biomedical activities. Coord. Chem. Rev. 2021, 447, 214143. [CrossRef]

83. Martínez-Valencia, B.; Corona-Motolinia, N.D.; Sánchez-Lara, E.; Noriega, L.; Sánchez-Gaytán, B.L.; Castro, M.E.; MeléndezBustamante, F.J.; González-Vergara, E. Cyclo-tetravanadate bridged copper complexes as potential double bullet pro-metallodrugs for cancer treatment. J. Inorg. Biochem. 2020, 208, 111081. [CrossRef] [PubMed]

84. Martínez-Valencia, B.; Corona-Motolinia, N.D.; Sánchez-Lara, E.; Sánchez-Gaytán, B.L.; Cerro-López, M.; Mendoza, A.; Castro, M.E.; Meléndez-Bustamante, F.J.; González-Vergara, E. Synthesis and Experimental-Computational Characterization of a Copper/Vanadium Compound with Potential Anticancer Activity. Crystals 2020, 10, 492. [CrossRef]

85. Sánchez-Lara, E.; García-García, A.; González-Vergara, E.; Cepeda, J.; Rodríguez-Diéguez, A. Magneto-structural correlations of cyclo-tetravanadates functionalized with mixed-ligand copper (ii) complexes. New J. Chem. 2021, 45, 5081-5092. [CrossRef] 
86. Corona-Motolinia, N.D.; Martínez-Valencia, B.; Noriega, L.; Sánchez-Gaytán, B.L.; Méndez-Rojas, M.A.; Melendez, F.J.; Castro, M.E.; González-Vergara, E. Synthesis, Crystal Structure, and Computational Methods of Vanadium and Copper Compounds as Potential Drugs for Cancer Treatment. Molecules 2020, 25, 4679. [CrossRef]

87. Macrae, C.F.; Bruno, I.J.; Chisholm, J.A.; Edgington, P.R.; McCabe, P.; Pidcock, E.; Rodriguez-Monge, L.; Taylor, R.; Van de Street, J.; Wood, P.A. Mercury CSD 2.0-New features for the visualization and investigation of crystal structures. J. Appl. Cryst. 2008, 41, 466-470. [CrossRef]

88. Sharma, R.P.; Ajnesh, S.; Venugopalan, P.; Dansby-Sparks, R.; Xue, Z.-L.; Rossetti, S.; Ferreti, V. Stabilization of tetrameric metavanadate ion by tris(1,10-phenanthroline)cobalt(III): Synthesis, spectroscopic, and X-ray structural study of $\left[\mathrm{Co}(\text { phen })_{3}\right]_{3}\left(\mathrm{~V}_{4} \mathrm{O}_{12}\right)_{2} \mathrm{Cl} \cdot 27 \mathrm{H}_{2} \mathrm{O}$. J. Coord. Chem. 2019, 63, 3016-3027. [CrossRef]

89. Kucsera, R.; Joniaková, D.; Zúrková, L. Thermal properties of $\left[\mathrm{M}^{\mathrm{II}}(\mathrm{phen})_{3}\right]_{2} \mathrm{~V}_{4} \mathrm{O}_{12}$ phen $22 \mathrm{H}_{2} \mathrm{O}\left(\mathrm{M}^{\mathrm{II}}=\mathrm{Co}, \mathrm{Ni}, \mathrm{Cu}, \mathrm{phen}=1\right.$, 10-phenanthroline). J. Therm. Anal. Calorim. 2004, 78, 263-272. [CrossRef]

90. Nakamoto, K. Infrared and Raman Spectra of Inorganic and Coordination Compounds, 6th ed.; John Wiley \& Sons, Inc.: Hoboken, NJ, USA, 2009

91. Bìcer, E.; Dege, N.; Coskun, E. Synthesis, characterization, and crystal structure of a novel decavanadate salt, $\left[\mathrm{V}_{0.50}\left(\mathrm{H}_{2} \mathrm{O}\right)_{5}\right]_{2}\left[\mathrm{H}_{2}\left(\mathrm{~V}_{10} \mathrm{O}_{28}\right)\right] \cdot 4\left(\mathrm{H}_{2} \mathrm{O}\right)$. J. Chil. Chem. Soc. 2017, 62, 3610-3614. [CrossRef]

92. Guilherme, L.R.; Massabni, A.C.; Dametto, A.C.; De Souza Correa, R.; Suman de Araujo, A. Synthesis, Infrared Spectroscopy and Crystal Structure Determination of a New Decavanadate. J. Chem. Crystallogr. 2010, 40, 897-901. [CrossRef]

93. Rakovsky, E.; Zurková, L.; Marek, J. Synthesis, Crystal Structure, and IR Spectroscopic Characterization of 1,6-Hexanediammonium Dihydrogendecavanadate. Mon. Chem. 2002, 133, 277-283. [CrossRef]

94. Wery, A.S.J.; Gutierrez-Zorrila, J.M.; Roman, P. Influence of protonation on crystal packing and thermal behavior of tertbutylammonium decavanadates. Polyhedron 1996, 15, 4555-4564. [CrossRef]

95. Román, P.; San José, A.; Luque, A.; Gutiérrez-Zorrila, J.M. Observation of a Novel Cyclic Tetrametavanadate Anion Isolated from Aqueous Solution. Inorg. Chem. 1993, 32, 775-776. [CrossRef]

96. Paredes-García, P.; Gaune, S.; Saldías, M.; Garland, M.T.; Baggio, R.; Vega, A.; Salah El Fallah, M.; Escuer, A.; Le Fur, E.; Venegas-Yazigi, D.; et al. Solvatomorphs of dimeric transition metal complexes based on the $\mathrm{V}_{4} \mathrm{O}_{12}$ cyclic anion as a building block: Crystalline packing and magnetic properties. Inorg. Chim. Acta 2008, 361, 3681-3689. [CrossRef]

97. Zhang, K.; Liang, D.; Wang, M.H. Bis[tris(2,2-bipyridyl-k2N, N)cobalt(II)] cyclo-tetravanadate undecahydrate. Acta Crystallogr. Sect. C Cryst. Struct. Commun. 2013, 69, 138-141. [CrossRef] [PubMed]

98. Byler, D.M.; Wilson, R.M.; Randall, C.S.; Sokoloski, T.D. Second derivative infrared spectroscopy as a non-destructive tool to assess the purity and structural integrity of proteins. Pharm. Res. 1995, 12, 446-450. [CrossRef]

99. Rieppo, L.; Saarakkala, S.; Närhi, T.; Helminen, H.J.; Jurvelin, J.S.; Rieppo, J. Application of second derivative spectroscopy for increasing molecular specificity of fourier transform infrared spectroscopic imaging of articular cartilage. Osteoarthr. Cartil. 2012, 20, 451-459. [CrossRef]

100. Smith, J.C.; Gonzalez-Vergara, E.; Vincent, J.B. Detection of structural changes upon oxidation in multinuclear Mn-oxo-carboxylate assemblies by Fourier transform infrared spectroscopy: Relationship to photosystem II. Inorg. Chim. Acta 1997, 225, 99-103. [CrossRef]

101. Schilt, A.A.; Taylor, R.C. Infra-red spectra of 1:10-phenanthroline metal complexes in the rock salt region below $2000 \mathrm{~cm}^{-1} . J$. Inorg. Nucl. Chem. 1959, 9, 211-221. [CrossRef]

102. Baskaran, S.; Krishnan, M.M.; Arumugham, M.N.; Kumar, R. DFT analysis and DNA binding, cleavage of copper(II) complexes. J. Mol. Liq. 2016, 221, 1045-1053. [CrossRef]

103. Barán, E.; Viera, I.; Torre, M.H. Vibrational spectra of the $\mathrm{Cu}(\mathrm{II})$ complexes of l-asparagine and l-glutamine. Spectrochim. Acta Part A 2007, 66, 114-117. [CrossRef]

104. Valora, G.; Munzi, G.; Bonomo, R.P. Ternary copper(II) complexes with 1, 10-phenanthroline and various aminoacidates: A spectroscopic and voltammetric study in aqueous solution. J. Inorg. Biochem. 2019, 191, 40-48. [CrossRef] [PubMed]

105. Lever, A.B.P. Inorganic Electronic Spectroscopy, 2nd ed.; Elsevier: Amsterdam, The Netherlands, 1984; p. 356.

106. Agudelo, D.; Bourassa, P.; Beauregard, M.; Bérubé, G.; Tajmir-Riahi, H.A. tRNA binding to antitumor drug doxorubicin and its analogue. PLoS ONE 2013, 8, e69248. [CrossRef]

107. García-Ramos, J.C.; Tovar-Tovar, A.; Hernández-Lima, J.; Cortés-Guzmán, F.; Moreno-Esparza, R.; Ruiz-Azuara, L. A new kind of intermolecular stacking interaction between copper(II) mixed chelate complex (Casiopeína III-ia) and adenine. Polyhedron 2011, 30, 2697-2703. [CrossRef]

108. Parveen, S.; Fatima, K.; Zehra, S.; Arjmand, F. RNA-targeted Cu(II)-based potential antitumor drug entity: Comprehensive structural, biological \{DNA/RNA binding, cleavage, cytotoxicity\} and computational studies. J. Biomol. Struct. Dyn. 2020, 39, 6070-6083. [CrossRef]

109. Constable, E.C.; Housecroft, C.E. The early years of 2, 2'-bipyridine-A ligand in its own lifetime. Molecules $2019,24,3951$. [CrossRef] [PubMed]

110. Bencini, A.; Lippolis, V. 1,10-Phenanthroline: A versatile building block for the construction of ligands for various purposes. Coord. Chem. Rev. 2010, 254, 2096-2180. [CrossRef]

111. Alvarez, N.; Kramer, M.G.; Ellena, J.; Costa-Filho, A.; Torre, M.H.; Facchin, G. Copper-diimine coordination compounds as potential new tools in the treatment of cancer. Cancer Rep. Rev. 2018, 2, 1-5. [CrossRef] 
112. Tabatabaee, M.; Ahadiat, G.; Molčanov, K. Tetrakis (2-amino-4-methylpyridinium) cyclo-tetra- $\mu 2$-oxido-tetrakis [dioxidovanadate (V)] tetrahydrate. Acta Crystallogr. Sect. E Struct. Rep. Online 2011, 67, m1090. [CrossRef]

113. Wéry, A.S.J.; Gutiérrez-Zorrilla, J.M.; Luque, A.; Ugalde, M.; Román, P. Phase transitions in metavanadates. Polymerization of tetrakis (tert-butylammonium)-cyclo-tetrametavanadate. Chem. Mater. 1996, 8, 408-413. [CrossRef]

114. Chen, B.; Huang, X.; Wang, B.; Lin, Z.; Hu, J.; Chi, Y.; Hu, C. Three New Imidazole-Functionalized Hexanuclear Oxidovanadium Clusters with Exceptional Catalytic Oxidation Properties for Alcohols. Chem.-A Eur. J. 2013, 19, 4408-4413. [CrossRef]

115. Li, C.; Zhong, D.; Huang, X.; Shen, G.; Li, Q.; Du, J.; Dou, J. Two organic-inorganic hybrid polyoxovanadates as reusable catalysts for Knoevenagel condensation. New J. Chem. 2019, 43, 5813-5819. [CrossRef]

116. Huang, M.H.; Bi, L.H.; Dong, S.J. Bis[tris(2, 2'-bipyridyl-k2N, N') iron (II)] cyclo-tetravanadate decahydrate. Acta Crystallogr. Sect. E Struct. Rep. Online. 2004, 60, m153-m155. [CrossRef]

117. Zhang, X.M. catena-Poly[[bis [triaqua [2, 5-bis (4-pyridyl)-1, 3, 4-thiadiazole] cobalt (II)]]- $\mu 4$-tetravanadato]. Acta Crystallogr. Sect. E Struct. Rep. Online 2004, 60, m1411-m1413. [CrossRef]

118. Xiao, D.; Hou, Y.; Wang, E.; Lü, J.; Li, Y.; Xu, L.; Hu, C. Dehydrogenative coupling of 2, 2'-bipyridine: Hydrothermal synthesis and crystal structure of a novel polyoxovanadate decorated with the $2,2^{\prime} ; 6^{\prime}, 2^{\prime \prime} ; 6^{\prime \prime}, 2^{\prime \prime \prime}$-quaterpyridine ligand. Inorg. Chem. Commun. 2004, 7, 437-439. [CrossRef]

119. Xie, A.; Xu, D.; Xu, Y.; Zhou, K. Synthesis, Crystal Structure and Electrochemical Behaviour of Tris (1, 10-phenanthroline) zinc (II) Tetrametavanadate Octahydrate. Acta Chim. Sin. 1997, 55, 853-859.

120. Xing, Y.; Zhang, Y.; Sun, Z.; Ge, M.; Yuan, H.; Zhang, B. Synthesis, Structure Characterization, and Quantum Chemistry of a Discrete Cluster $\left[\left\{\mathrm{Zn}\left(2,2^{\prime}\right.\right.\right.$-bipy) 3$\left.\} 2 \mathrm{~V}_{4} \mathrm{O}_{12}\right] \bullet 11 \mathrm{H}_{2} \mathrm{O}\left(2,2^{\prime}\right.$-bipy = 2, 2'-bipyridine). Synth. React. Inorg. Met.-Org., Nano-Met. Chem. 2005, 35, 747-753. [CrossRef]

121. Wang, Q.-W.; Shi, L.-F.; Gao, G.-G.; Li, C.-B.; Han, L. Synthesis and Crystal Structure of a Novel Tetravanadate Modified.by Chiral Racemoid Zirconium Complex. Jiegou Huaxue 2006, 25, 979-984.

122. Sun, Y.; Xu, Y.; Liu, S.; Wang, J.; Gao, D.; Zhang, G. Four inorganic-organic hybrid complexes built from tetravanadate and macrocyclic oxamide. J. Coord. Chem. 2013, 66, 2516-2528. [CrossRef]

123. Yucesan, G.; Armatas, N.G.; Zubieta, J. Hydrothermal synthesis of molecular oxovanadium compounds. The crystal and molecular structures of $\left[\mathrm{VO}_{2}(\right.$ terpy) $] \mathrm{NO}_{3},\left[\mathrm{VO}\right.$ (terpy) $\left.\left(\mathrm{OH}_{3} \mathrm{PC}_{6} \mathrm{H}_{5}\right)_{2}\right],\left[\left\{\mathrm{Cu}\left(\mathrm{H}_{2} \mathrm{O}\right)(\right.\right.$ terpy) $\left.\} \mathrm{V}_{2} \mathrm{O}_{6}\right],\left[\{\mathrm{Cu}(\mathrm{ttbterpy})\} \mathrm{V}_{2} \mathrm{O}_{6}\right]$ and $[\{\mathrm{Cu}$ (ttbterpy) $\left.\} \mathrm{VO}_{2}\left(\mathrm{HO}_{3} \mathrm{PCH}_{2} \mathrm{PO}_{3}\right)\right] \bullet \mathrm{H}_{2} \mathrm{O}$ (terpy = 2, 2': 6', $2^{\prime \prime}$-terpyridine; ttbterpy = 4, 4', 4 "'-tri-tert-butyl-2, 2': 6', 2"'-terpyridine). Inorg. Chim. Acta 2006, 359, 4557-4564.

124. Smith, T.M.; Freund, S.R.; Lau, A.; Varges, J.; Spinu, L.; Zubieta, J. Investigations of organic-inorganic hybrid materials: Ligand influences on the structures of copper-vanadium oxide materials. Inorg. Chim. Acta 2014, 414, 91-96. [CrossRef]

125. Corona-Motolinia, N.D.; Martínez-Valencia, B.; Noriega, L.; Sánchez-Gaytán, B.L.; Méndez-Rojas, M.A.; Melendez, F.J.; Castro, M.E.; González-Vergara, E. Unpublished work. 2021.

126. Ruiz-Azuara, L. Process to Obtain New Mixed Copper Aminoacidate Complexes from Phenylate Phenathrolines to Be Used as Anticancerigenic Agents. European Patent EP 0434444A1, 26 June 1991.

127. Ruiz-Azuara, L. Process to Obtain New Mixed Copper Aminoacidate from Methylate Phenanthroline Complexes to Be Used as Anticancerigenic Agents. USA Patent No. 5,576,326, 19 November 1996.

128. Ruiz-Azuara, L. Process to Obtain New Mixed Copper Aminoacidate Complexes from Phenylate Phenanthroline to Be Used as Anticancerigenic Agents. USA Patent No. 35458, 18 February 1997.

129. Ruiz-Azuara, L.; Bastian, G.; Bravo-Gómez, M.E.; Cañas, R.C.; Flores-Alamo, M.; Fuentes, I.; Mejia, C.; García-Ramos, J.C.; Serrano, A. Abstract CT408: Phase I study of one mixed chelates copper(II) compound, Casiopeína CasIIIia with antitumor activity and its mechanism of action. Cancer Res. 2014, 74 (suppl. 19), CT408. [CrossRef]

130. Patra, A.K.; Roy, S.; Chakravarty, A.R. Synthesis, crystal structures, DNA binding and cleavage activity of L-glutamine copper(II) complexes of heterocyclic bases. Inorg. Chim. Acta 2009, 362, 1591-1599. [CrossRef]

131. Xu, Y.; Zhang, Q.; Lin, F.; Zhu, L.; Huang, F.; Zhao, L.; Ou, R. Casiopeina II-gly acts on lncRNA MALAT1 by miR-17-5p to inhibit FZD2 expression via the Wnt signaling pathway during the treatment of cervical carcinoma. Oncol. Rep. 2019, 42, 1365-1379. [CrossRef] [PubMed]

132. Ugone, V.; Pisanu, F.; Sanna, D.; Garriba, E. Interaction of the potent antitumoral compounds Casiopeinas®with blood serum and cellular bioligands. J. Inorg. Biochem. 2021, 224, 111566. [CrossRef]

133. Becco, L.; García-Ramos, J.C.; Azuara, L.R.; Gambino, D.; Garat, B. Analysis of the DNA interaction of copper compounds belonging to the Casiopeínas ®antitumoral series. Biol. Trace Elem. Res. 2014, 161, 210-215. [CrossRef] [PubMed]

134. Dolomanov, O.V.; Bourhis, L.J.; Gildea, R.J.; Howard Puschmann, J.A.K. OLEX2: A complete structure solution, refinement, and analysis program. J. Appl. Crystallogr. 2009, 42, 339-341. [CrossRef]

135. Sheldrick, G.M. A short history of SHELX. Acta Cryst. 2008, A64, 112-122. [CrossRef]

136. Sheldrick, G.M. Crystal Structure Refinement with SHELXL. Acta Crystallogr. Sect. C Struct. Chem. 2015, 71, 3-8. [CrossRef] [PubMed]

137. Becke, A.D. Density-functional thermochemistry. III. The role of exact exchange, J. Chem. Phys. 1993, 98, 5648-5652.

138. Grimme, S.; Ehrlich, S.; Goerigk, L. Effect of the damping function in dispersion corrected density functional theory. J. Comp. Chem. 2011, 32, 1456-1465. [CrossRef] 
139. Weigend, F.; Ahlrichs, R. Balanced basis sets of split valence, triple zeta valence, and quadruple zeta valence quality for $H$ to Rn: Design and assessment of accuracy. Phys. Chem. Chem. Phys. 2005, 7, 3297-3305. [CrossRef]

140. Dunning, T.H., Jr.; Hay, P.J. Methods of Electronic Structure Theory. In Modern Theoretical Chemistry; Schaefer, H.F., III, Ed.; Plenum: New York, NY, USA, 1977; Volume 3, pp. 1-28.

141. Hay, P.J.; Wadt, W.R. Ab initio effective core potentials for molecular calculations-Potentials for the transition-metal atoms Sc to Hg. J. Chem. Phys. 1985, 82, 270-283. [CrossRef]

142. Cossi, M.; Barone, V.; Cammi, R.; Tomasi, J. Ab initio study of solvated molecules: A new implementation of the polarizable continuum model. Chem. Phys. Lett. 1996, 255, 327-335. [CrossRef]

143. Frisch, M.J.; Trucks, G.W.; Schlegel, H.B.; Scuseria, G.E.; Robb, M.A.; Cheeseman, J.R.; Scalmani, G.; Barone, V.; Petersson, G.A.; Nakatsuji, H.; et al. Gaussian 16, Revision, B; Gaussian Inc.: Wallingford, CT, USA, 2016.

144. Dennington, R.; Keith, T.; Millam, J. Gauss View, Version 6.0.16; Semichem Inc.: Shawnee Mission, KS, USA, 2016.

145. Domingo, L.R.; Ríos-Gutiérrez, M.; Pérez, P. Applications of the Conceptual Density Functional Theory Indices to Organic Chemistry Reactivity. Molecules 2016, 21, 748. [CrossRef] [PubMed]

146. Keith, T.A. TK Gristmill Software; Version 19.02.13; AIMAll: Overland Park, KS, USA, 2019.

147. Drew, H.R.; Wing, R.M.; Takano, T.; Broka, C.; Tanaka, S.; Itakura, K.; Dickerson, R.E. Structure of a B-DNA dodecamer: Conformation and dynamics. Proc. Natl. Acad. Sci. USA 1981, 78, 2179-2183. [CrossRef] [PubMed]

148. Lipscomb, L.A.; Peek, M.E.; Zhou, F.X.; Bertrand, J.A.; VanDerveer, D.; Williams, L.D. Water ring structure at DNA interfaces: Hydration and dynamics of DNA-anthracycline complexes. Biochemistry 1994, 33, 3649-3659. [CrossRef]

149. Sussman, J.L.; Holbrook, S.R.; Warrant, R.W.; Church, G.M.; Kim, S.H. Crystal structure of yeast phenylalanine transfer RNA. I. Crystallographic refinement. J. Mol. Biol. 1978, 123, 607-630. [CrossRef]

150. Gilad, Y.; Senderowitz, H. Docking studies on DNA intercalators. J. Chem. Inf. Model. 2014, 54, 96-107. [CrossRef] [PubMed]

151. Morris, G.M.; Huey, R.; Lindstrom, W.; Sanner, M.F.; Belew, R.K.; Goodsell, D.S.; Olson, A.J. Autodock4 and AutoDockTools4: Automated docking with selective receptor flexibility. J. Comput. Chem. 2009, 16, 2785-2791. [CrossRef] [PubMed]

152. Biovia Discovery Studio. Available online: https://discover.3ds.com/discovery-studio-visualizer-download (accessed on 24 September 2021).

153. García-García, A.; Noriega, L.; Meléndez-Bustamante, F.J.; Castro, M.E.; Sánchez-Gaytán, B.L.; Choquesillo-Lazarte, D.; GonzálezVergara, E.; Rodríguez-Diéguez, A. 2-Aminopyrimidinium Decavanadate: Experimental and Theoretical Characterization, Molecular Docking, and Potential Antineoplastic Activity. Inorganics 2021, 9, 67. [CrossRef] 